British \& Irish Botany 2(4): 309-334, 2020

\title{
A review of the ecology and status of the Kerry Lily Simethis mattiazzii ( $S$. planifolia) Asphodelaceae in Ireland
}

\author{
Darach Lupton ${ }^{1}$; Micheline Sheehy Skeffington ${ }^{2 *}$ \\ ${ }^{1}$ Oman Botanic Garden, Muscat, Sultanate of Oman; ${ }^{2}$ Clarinbridge, Co. Galway, Ireland
}

*Corresponding author: Micheline Sheehy Skeffington: michelinesheehy@gmail.com

This pdf constitutes the Version of Record published on $7^{\text {th }}$ December 2020

\begin{abstract}
The distribution, habitat and genetic diversity of Irish populations of the Kerry Lily (Simethis mattiazzii) are described. All sites known in 2009, centred around Kenmare Bay in SW Ireland, were sampled. The species occurs in a relatively uniform plant community, classified as 4030 Dry Heath within a low-lying coastal heath complex. A preliminary genetic investigation involving analysis of 21 chloroplast and nuclear gene regions revealed no genetic diversity in the samples examined, suggesting that the species in Ireland comprises a number of metapopulations, within one large, single population confined to the Derrynane area on the Iveragh peninsula in South-west Kerry (v.c.H1) and one on the north of the Beara peninsula, across Kenmare Bay from Derrynane, in West Cork (v.c.H3). A sixth site, at Cahergarriff on the south of the Beara Peninsula has since been discovered. Of the 5,750 flowering plants recorded in 2009, the biggest meta-population, which also had the highest plant density, numbered 2,364, on Abbey Island, near Derrynane. Results from two brief surveys in 2020 indicate that the populations have reduced in extent and size since 2009. The genetic results so far suggest that the species is genetically depauperate in Ireland, such that the Irish populations may in fact be only represented by a single, or narrow, founder genotype and may be the result of a one-off introduction. The potential mode of arrival of the species to Ireland is discussed in relation to trade with continental Europe, where its distribution is greatest in SW France and western Iberia. A follow-up genetic study is required to confirm these results and explore a putative point of origin for the species in Ireland. Conservation issues are addressed in the light of these observations.
\end{abstract}

Keywords: disjunct distribution; heathland; Hiberno-Lusitanian species; genetic diversity; smuggling; conservation

\section{Introduction}

The Kerry Lily, Simethis mattiazzii (Fig. 1) is a diminutive, white-flowered member of the Asphodelaceae (Webb, 1980). It is one of a group of plants that occur in Ireland, largely near the west coast, but are absent from Britain and are variously termed the Lusitanian (Scully, 1916), Pyrenean-Mediterranean (Praeger, 1934) or Mediterranean-Atlantic (Webb, 1983) element of the Irish flora. Most, if not all of these are at the northernmost limit of their European range in Ireland and represent an important element of the European flora that has 
long fascinated botanists in Ireland (e.g. Hennessy, 1867; Scully, 1916; Praeger, 1934; Webb, 1983). Many are rare in Ireland and as such, have been the focus of research and conservation measures, such as in this study.

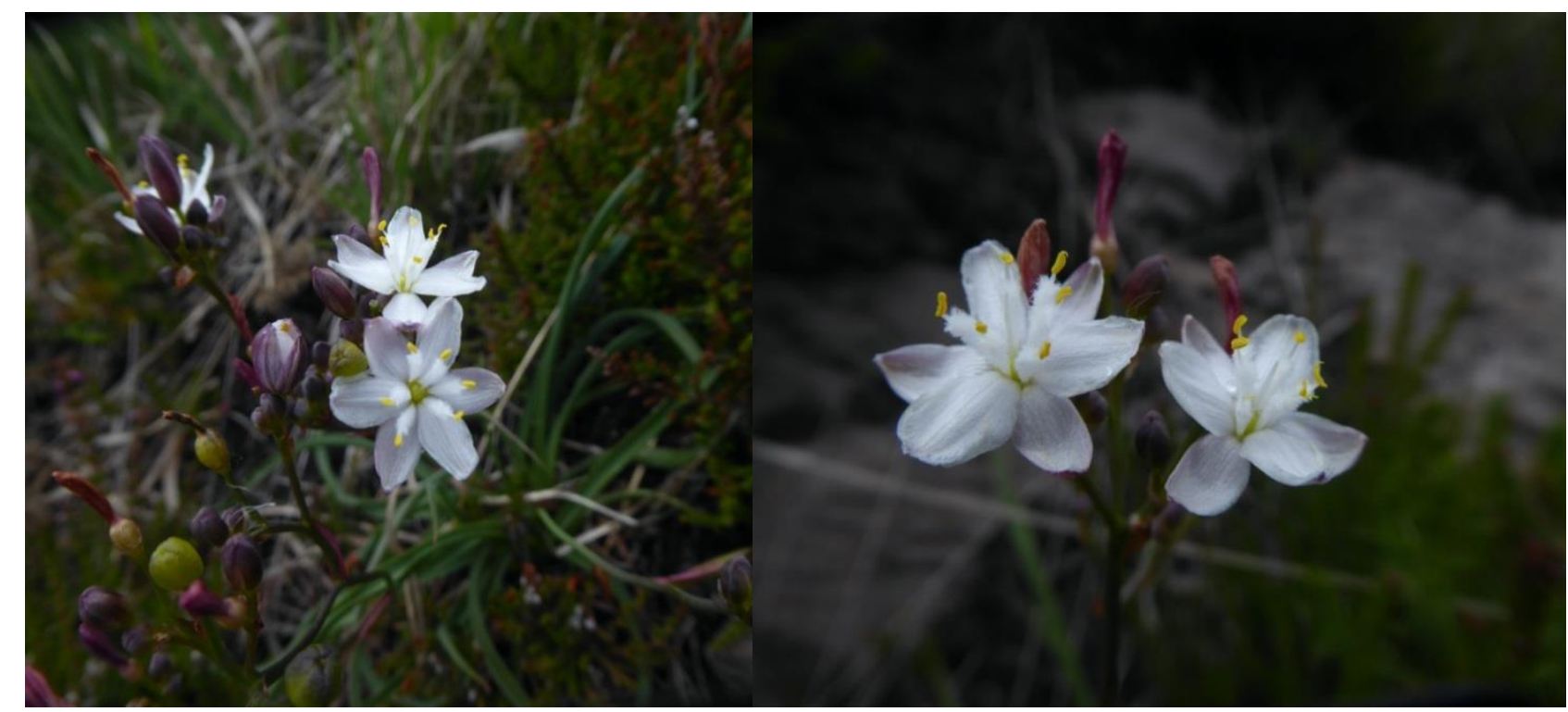

Figure 1. Simethis mattiazzii at Cahergarriff, Beara Peninsula, West Cork. Note seed capsules ripening at the bottom of the left-hand photo. Images: Rory Hodd

Simethis mattiazzii is largely a species of the south-western Atlantic region of Europe, where its main distribution is in south-west and western France (Tison \& de Foucault, 2014) and on the northern and western part of the Iberian Peninsula (Martínez Ortega, 2014) (Fig. 2). It extends eastwards to central regions of France, where much lowland heath is to be found, (Dupont, 2015) and otherwise occurs sporadically in the western Mediterranean, mainly on acidic soils, in western Italy and the north African coast eastwards to Tunisia (Maire, 1958; Gianguzzi et al., 2012; Dupont, 2015). The distribution is markedly disjunct when the Irish population is included, which is over $500 \mathrm{~km}$ away from the nearest population in Brittany, whereas its sporadic occurrences around the Mediterranean are more connected (Fig. 2).

In Ireland, it is only known from two adjacent peninsulas in the extreme south-west (Fig. 3 ). It was first found there by the Rev Thaddeus O'Mahony (in 1847/8) 'on hills near Derrynane Abbey, the seat of the O'Connells' (Harvey, 1848). By 1916, it had also been found west and east of Derrynane over about 10 miles $(16 \mathrm{~km})$ of 'wild rocky and furzy heath with a peaty soil' (Scully, 1916), which is still roughly the area it occupies on the Iveragh Peninsula today. It was not known elsewhere in Ireland until a population was found on the north side of the Beara Peninsula in West Cork, across Kenmare Bay from Derrynane, in 1987 by Nicholas Cummins (Scannell \& O'Donnell, 1994) and much more recently (2017) by Fionn Moore at Cahergarriff on the south side of the Beara Peninsula (BSBI Database https://database.bsbi.org/; Hodd, 2020). 


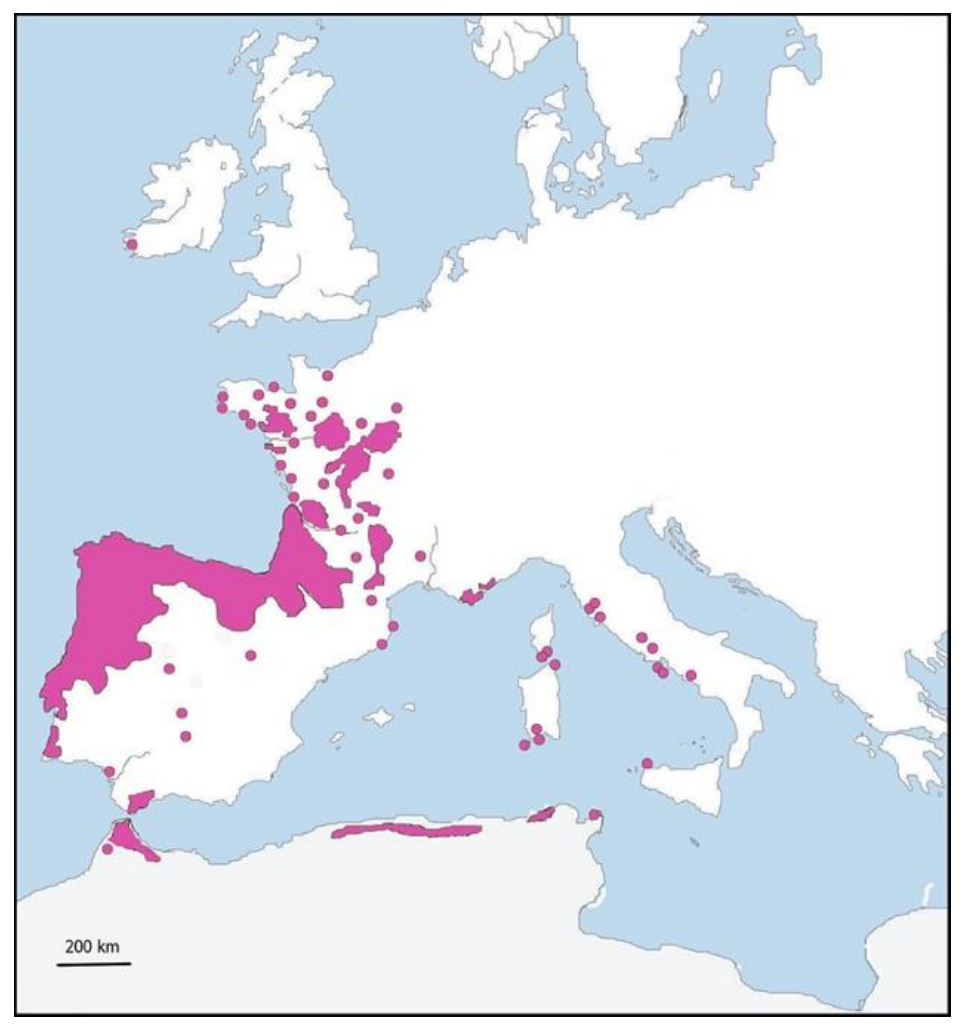

Figure 2. Current known distribution of Simethis mattiazzii. After Dupont, 1962; Gianguzzi et al., 2012; Dupont, 2015; Araújo et al., 2020; https://inpn.mnhn.fr/espece/cd nom/123708 (accessed 29.6.2020); http://www.anthos.es; https://flora-on.pt/\#/1simethis+mattiazzii

(accessed 24.7.2020). Dots are isolated occurrences

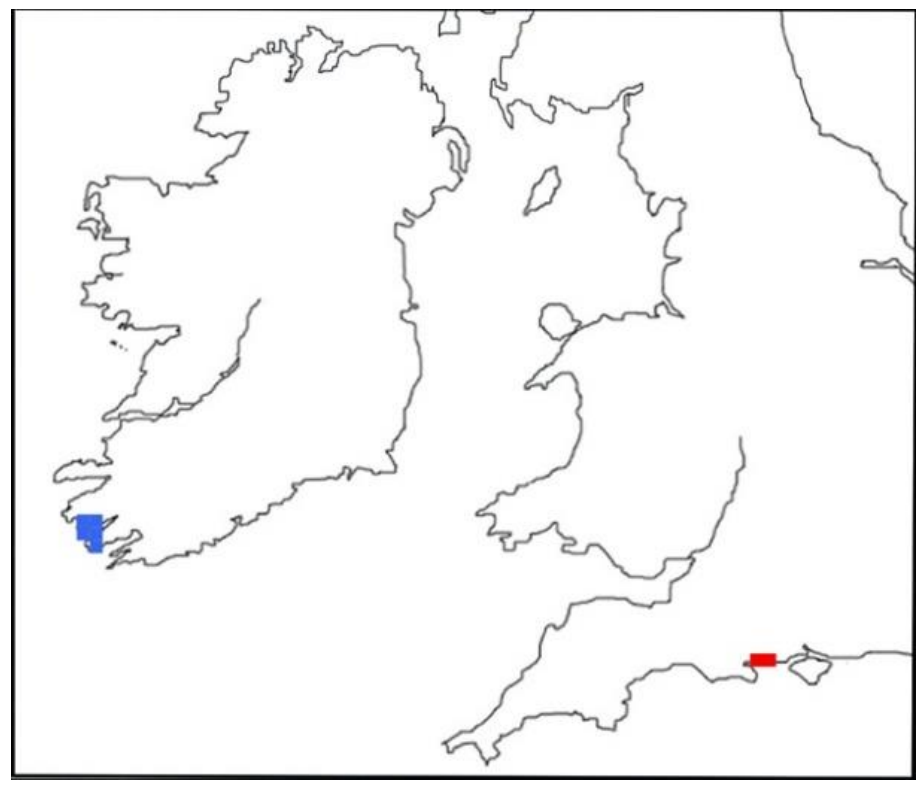

Figure 3. Distribution of Simethis mattiazzii in Ireland and Britain. Squares are hectads; blue $=$ considered native, red $=$ considered introduced, now extinct. Data from BSBI Database https://database.bsbi.org/ (accessed 22.6.2020) 
Coincidentally, it was found at roughly the same time in Britain, in 1847 (by Miss Wilkins) growing 'on what was once part of Poole heath', but which was by then in a Pinus pinaster plantation; the population was said to have been bisected by a road at the time of the plantation 'about forty years ago' (Borrer et al., 1849). The location is at Branksome, between Poole Harbour and Bournemouth in Dorset (Pearman \& Edgington, 2016) and was last seen there in 1925 (Good, 1948; Preston et al., 2002) (Fig. 3). There are various accounts of the plant in the adjacent county of Hampshire (Preston et al., 2002) and as surviving there at least until 1919 (Praeger, 1934), but it is not thought to be native at either site and the $P$. pinaster is said to have been imported from the Landes, south of Bordeaux (Pearman \& Edgington, 2016), where $S$. mattiazzii is a common plant of heathland (Dupont, 2015).

An Irish Red Data species, S. mattiazzii has been listed as Vulnerable (Curtis \& McGough, 1988 ) and is now considered Near Threatened and remains protected, under the Irish Flora (Protection) Order 2015 (Wyse Jackson et al., 2016). It is not on any other European national red list, but is considered 'vulnerable' or 'threatened' in parts of Italy, as well as being protected in Cataluña (Gianguzzi et al., 2012) and 'near threatened' in Andalucía (Cabezudo et al., 2005). In France it is also considered rare or vulnerable in outlying regions (https://inpn.mnhn.fr/espece/cd nom/123708/tab/statut).

As a local rarity, it has been regularly noted in the Iveragh Peninsula since it was first found. When mapped at monad level $(1 \mathrm{~km} \times 1 \mathrm{~km})$, the very localised distribution of the species is apparent (Fig. 4). However, this still only provides a broad overview of its occurrence in Ireland.

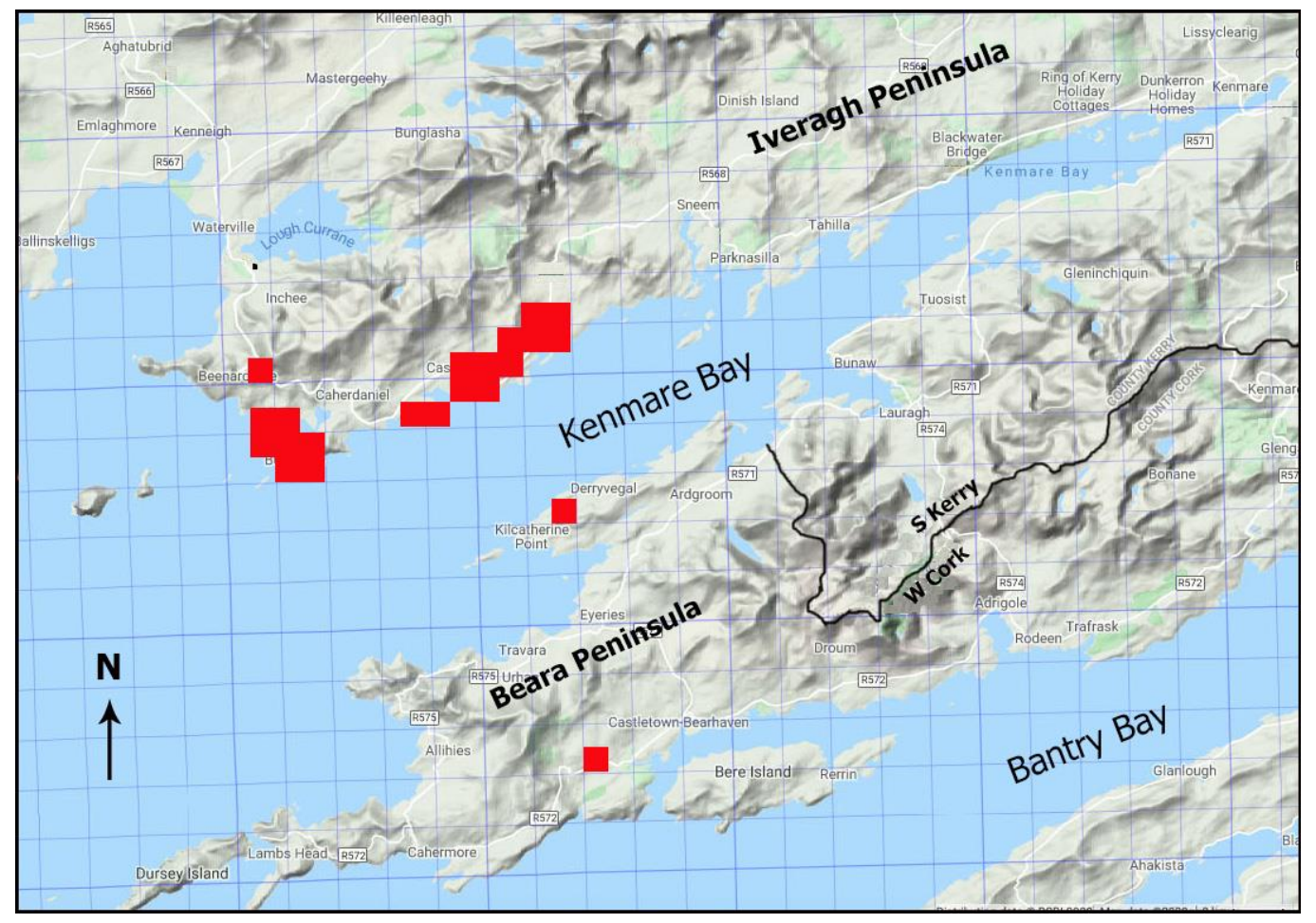

Figure 4. All currently known records that are at monad $(1 \mathrm{~km} \times 1 \mathrm{~km})$ scale for Simethis mattiazzif in Ireland. Based on BSBI Database (https://database.bsbi.org/) (accessed 15.8.2020) 
A detailed distribution of the individual Irish populations of $S$. mattiazzii had not been mapped by the time of the research in 2009 and only a short ecological study of the Derrynane population (Wyse Jackson, 1984) was done prior to that. To assess this enigmatic species' existence in Ireland, comprehensive information on its distribution is required. Data on the distribution, size of populations, plant communities and genetic diversity of $S$. mattiazzii in Ireland are provided here, and the possible origin of these populations, as well as the species' conservation requirements, are discussed.

\section{Methodology}

Population census

Herbarium material at the National Botanic Gardens Glasnevin (DBN) and Trinity College Dublin (TCD) was examined to determine the historical distribution of the species. Additional data were gathered from the records at the Irish National Parks and Wildlife Service and National Biodiversity Data Centre. A population census was carried out from June $15^{\text {th }}$ to July $20^{\text {th }} 2009$ during the species' peak flowering period. The location of all flowering plants was recorded using a Garmin eTrex GPS. For further details, see Lupton (2009). Using maps based on records in the BSBI database (https://database.bsbi.org/), the population area was subsequently deduced per site from the number of adjacent $100 \times 100$ m squares, which encompass all the 2009 GPS records of this study (Fig. 5).

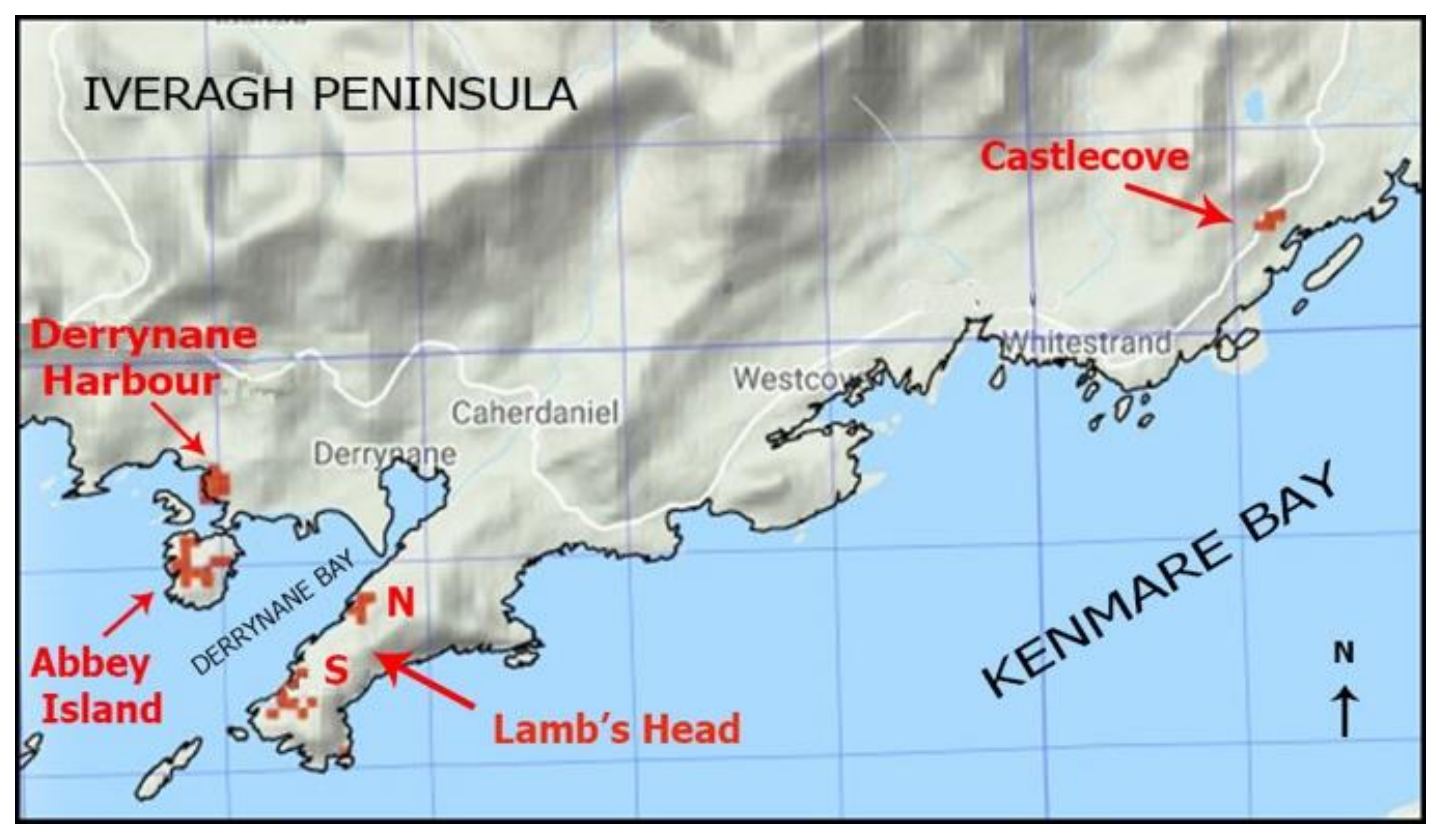

Figure 5. The four population sites for Simethis mattiazzii in South Kerry, as recorded in 2009. All the GPS records are here grouped into, and represented by, $100 \times 100 \mathrm{~m}$ squares. The West Cork Derreenacush population on the north shore of the Beara Peninsula (see Fig. 4) was contained within a single $100 \times 100 \mathrm{~m}$ square, so is not included here. Data from BSBI Database https://database.bsbi.org/ (accessed 16.8.2020) 


\section{Genetic diversity}

To examine heterogeneity within and among the $S$. mattiazzii populations in SW Ireland, seven individuals, randomly picked from each known site (two each from Derrynane Harbour and Castlecove; one each from Lamb's Head, Abbey Island and Dereenacush) were collected during the population census, and investigated in 2009. Within these individuals, 21 noncoding DNA sequences known to offer a high level of variation at an intra-specific level, were tested (Kress et al., 2005; Shaw et al., 2005; Shaw et al., 2007). Standard polymerase chain reactions (PCRs) were performed using an Eppendorf thermal cycler. Products were run on agarose gel to identify regions that amplified successfully. Amplified regions were purified using the QIAquick PCR Purification Kit and were sent to Eurofins MWG Operon (Ebersberg, Germany) for sequencing. Sequences of the seven individuals were compared for each region respectively to find variability in genetic composition among individuals. Comparisons of gene sequences were carried out using Sequencer version 4.9.

\section{Vegetation survey}

Most of the sites were re-visited on July $6^{\text {th }}-8^{\text {th }} 2020$ and relevés taken from $2 \times 2 \mathrm{~m}$ quadrats for each population found. Relevés at the Abbey Island population were taken on $19^{\text {th }}$ September 2020. Extremely difficult terrain precluded locating further sites at Castlecove. An extensive search at Derreenacush lead to the conclusion that the population at that site has shrunk considerably, allowing only one relevé to be taken. Nomenclature follows Stace (2019) for higher plants and Hodgetts et al. (2020) for bryophytes. Species cover-abundance was recorded using the Braun-Blanquet scale of cover-abundance (Kent, 2012). The number of $S$. mattiazzii plants and the number with flower spikes were recorded within each quadrat. The percent cover of the main plant functional types was also recorded; the vegetation height and soil depth estimated from a mean of five measurements and slope and aspect recorded in each quadrat.

\section{Results}

\section{Distribution}

In 2009, four main populations were identified in south-west Kerry (South Kerry, v.c.H1); at Derrynane Harbour; on Abbey Island and on Lamb's Head, all flanking the entrance to Derrynane Bay and in the Castlecove area c.5 km further east (Fig. 5). The fifth population was in west Cork (West Cork, v.C.H3), on the north shore of the Beara Peninsula at Dereenacush (see Fig. 4). The recently-found Cahergarriff site on the south of the Beara Peninsula (Fig. 4) was described in 2019 (Hodd, 2020).

By far the most widespread occurrence of the species is on the south coast of S Kerry, since the Derreenacush site, though with numerous plants, was confined within an area of 100 $x 100 \mathrm{~m}$. What is notable about the distribution of the populations is the separate nature of each group in the Derrynane area, comprising three of the five populations studied (Fig. 5). Though suitable habitat is present in much of that area, the plant seems to occur in discrete groupings. This distribution pattern was transposed onto the oldest available detailed map, the c. 1845 O.S. 6" map (Fig. 6). Field work, combined with a study of this map, showed that in each case, there is a sheltered cove providing a hidden landing place for small boats near each population. The species does not occur near the wider bays and more open-access piers, but 
would appear to be confined to an area near a small cove and mooring-place with a beach that is hidden from sight from the open sea. Some have small tracks leading to them, or obvious route-ways leading inland nearby; no actual road existed adjacent to any in 1845.

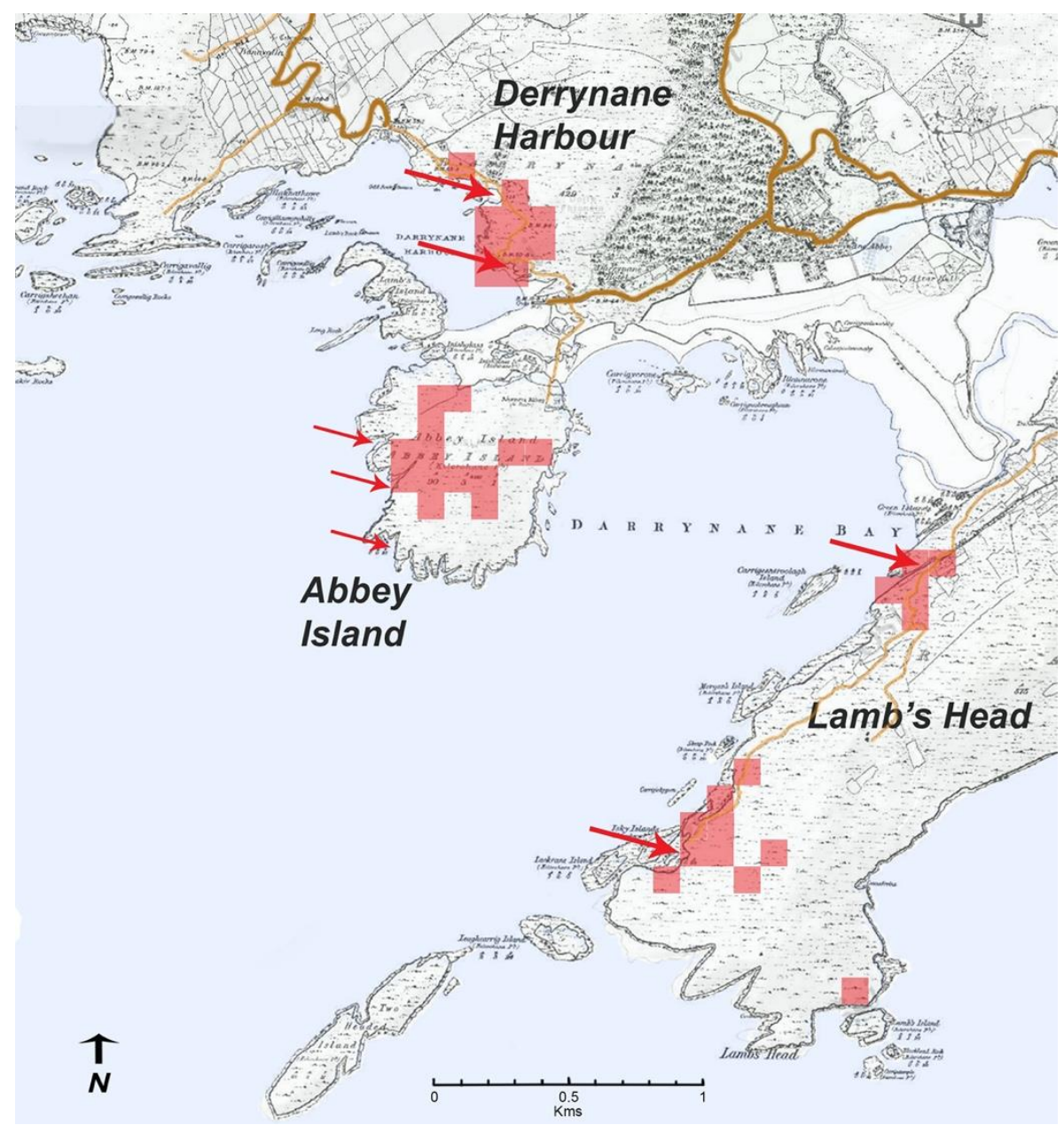

Figure 6. All 2009 records $(100 \times 100 \mathrm{~m})$ for Simethis mattiazzii, in Derrynane Bay region of S Kerry. Arrows indicate the narrow coves with beaches in the area, or on Abbey Island, hidden possible unloading places. Main tracks (light brown) and roads (dark brown) existing at the time of the 0.S. 6" Cassini map (c.1845; http://map.geohive.ie/mapviewer.html\#) are indicated

Discrete coves with landing-beaches, hidden from off-shore view by small islands, also occur along the coast associated with the Castlecove-Glanlough records, mapped at $100 \mathrm{~m} \mathrm{x}$ $100 \mathrm{~m}$ scale in Fig. 7 which shows these records to be adjacent to a road inland from the coast. However, data unavailable at the time of the 2009 study show the species to be more widespread in the area than shown at that scale (see Fig. 4). As those sites have not been mapped in detail, the actual occurrence of the species there, whether in separate populations next to the sea or not, or in an extensive continuous area, is as yet not known. 


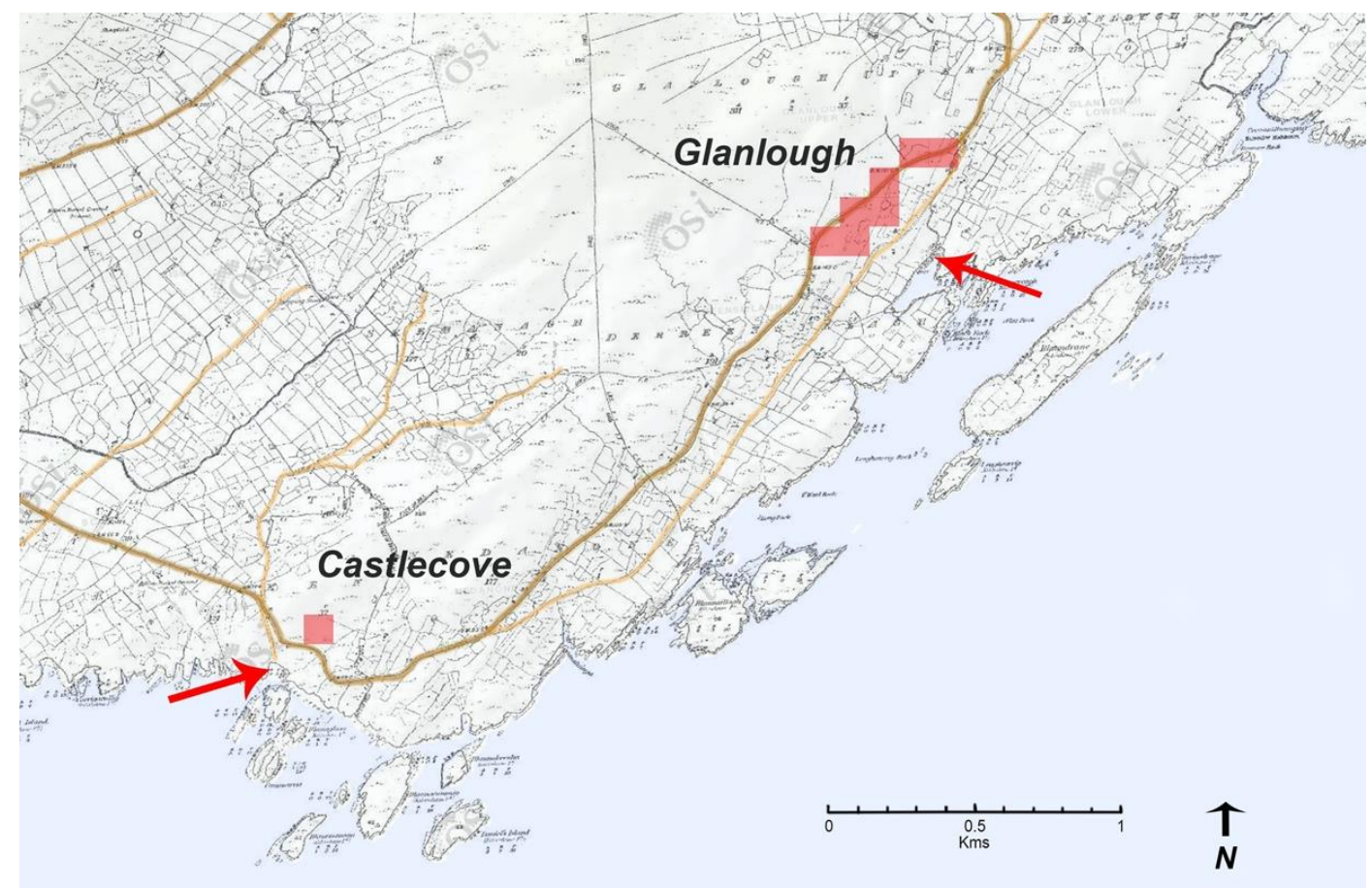

Figure 7. All S. mattiazzii records currently known at the $100 \mathrm{~m} \times 100 \mathrm{~m}$ scale in the Castlecove - Glanlough region of S Kerry. Arrows indicate narrow coves in the area. Main tracks (light brown) and roads (dark brown) existing at the time of the 0.S. 6" Cassini map (c.1845; http://map.geohive.ie/mapviewer.html\#) are indicated. NB the species also occurs in the area between the two sites (see Fig. 4), but has not been mapped there to this scale

\section{Population census}

The four populations on the Iveragh Peninsula in 2009 had a mean number of 1,131 flowering plants per site, however plant density per square metre varied considerably (Table 1 ). The largest recorded number of plants $(2,634)$ was at Abbey Island, which had the highest plant density of $0.0203 \mathrm{~m}^{-2}$, though, because the plants occur in clusters often far apart, these estimates can only be rough (Table 1). As the Cahergarriff population in W Cork was not known in 2009, it has been only recently counted and is not strictly comparable. The numbers are high, but the density is less comparable, as plant numbers were confined to a small restricted site (Hodd, 2020).

\section{Habitat and vegetation description}

The populations are predominantly located in an exposed, low-lying and undulating coastal landscape with a mosaic of habitats ranging mostly from Wet Heath ( $\mathrm{HH} 3)$ (sensu Fossitt, 2000) in the hollows, dominated by Molinia caerulea, to Dry Siliceous Heath (HH1) on ridge outcrops. S. mattiazzii is located mostly on these sandstone ridges and the sites examined were found to be on very shallow peat (in only one quadrat was it $>30 \mathrm{~cm}$ deep), with several quadrats comprising $20-25 \%$ bare ground and the highest rock cover of $30 \%$ was in Cahergarriff (Table 2). In most cases the quadrats were on steep slopes, with five on slopes of 
$45^{\circ}-70^{\circ}$. The average vegetation height was not more than $35 \mathrm{~cm}$, enabling the $S$. mattiazzii leaves and flowers (if any) to emerge above the low shrub and grass canopy (Fig. 8).

Table 1: Simethis mattiazzii population size estimates based on number of recorded flowering plants in 2009, and in June 2019 for Cahergarriff (Hodd, 2020). All sites are in South Kerry (v.c.H1) except for Derreenacush and Cahergarriff in Co. Cork (v.c.H3)

\begin{tabular}{llll} 
Metapopulation & $\begin{array}{l}\text { No. flowering } \\
\text { plants in } \mathbf{2 0 0 9}\end{array}$ & $\begin{array}{l}\text { Population } \\
\text { area } \mathbf{~ k m}^{\mathbf{2}}\end{array}$ & $\begin{array}{l}\text { Plant } \\
\text { density } \mathbf{~ m}^{-2}\end{array}$ \\
\hline Derrynane Harbour & 1262 & 0.09 & 0.014 \\
Castlecove & 546 & 0.04 & 0.0137 \\
Lamb's Head N* & 466.54 & 0.05 & 0.0093 \\
Lamb's Head S* & 746.46 & 0.08 & 0.0093 \\
Abbey Island & 2634 & 0.13 & 0.0203 \\
\hline & 1131 & & \\
Derreenacush & 95 & 0.01 & 0.0095 \\
Cahergarriff $\dagger$ & $\underline{275 \dagger}$ & $0.0003 \dagger$ & 0.9167
\end{tabular}

* Subtotals derived from overall total for Lamb's Head, proportional to site area; +Data from field work in 2019 (Hodd, 2020)

The plant community for all sites surveyed was remarkably uniform. The dominant vegetation comprised the low shrubs Calluna vulgaris and Ulex gallii, often accompanied by Erica cinerea and/or $E$. tetralix (Table 2). The percent small shrub cover ranged from $30-90 \%$ and the graminoid cover did not exceed $30 \%$. The dominant grass was Molinia caerulea, though usually with no more than c. $10 \%$ cover; Carex binervis and C. panicea were frequent, with usually low cover. Due to the dense small shrub canopy, bryophytes had a low cover (mostly $<20 \%$ ), with Campylopus species and Cladonia lichens forming a pioneer stage on denuded ground. $S$. mattiazzii seems to occur mainly on the slopes of the sandstone ridges, which may often have too-shallow soils for it to thrive on the flatter tops.

At most sites there were many smaller, presumably younger, plants in short vegetation or on bare soil; they were rare or absent from areas of dense vegetation such as at quadrat 3 (Fig. 8), where the species was mostly confined to the more open vegetation at the edges of the quadrat. 


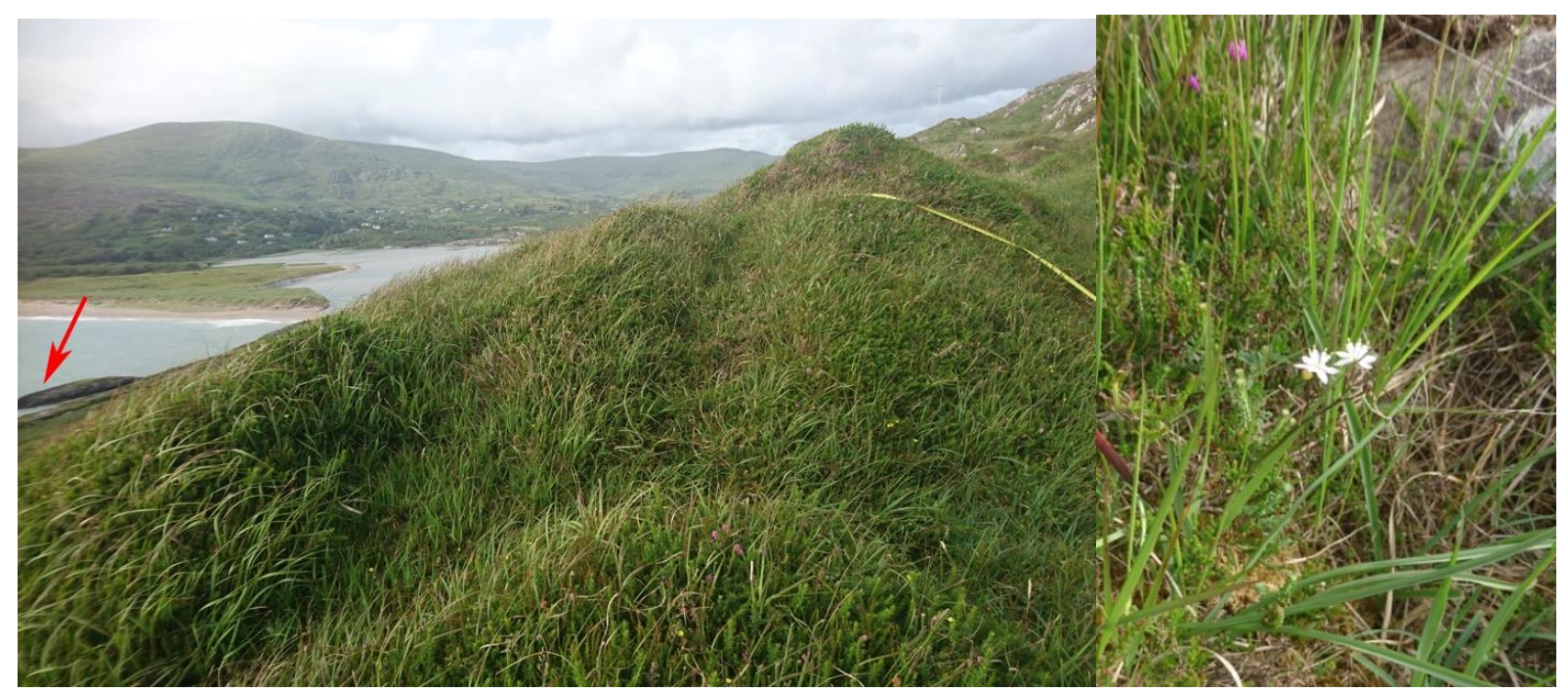

Figure 8. Quadrat 3 at Lamb's Head North (left). Inner Derrynane Bay in middle distance; arrow indicates nearby narrow cove (see Fig. 6) just visible on left. Simethis was mostly on the edges of the quadrat (right). Photos taken 6.7.2020

Table 2. Relevés taken in $\mathbf{2 0 2 0}$ from each of the six sites, as well as one from Cahergarriff (from Hodd, 2020). Burnt = fire, except in relevés $2 \& 5$ (DN) and 4 (CC) where drought on shallow soils and wind burn are more likely causes; $\mathrm{fl}=$ flower. Plant species are recorded using the Braun-Blanquet scale of cover-abundance; $+=\langle 1 \%$ cover; $1=1-5 \%$; $2=6$ $25 \% ; 3=26-50 \% ; 4=51-75 \% ; 5=76-100 \%$ (Kent, 2012). In sequence: CG = Cahergarriff; DN = Derrynane; LHN = Lamb's Head North; CC = Castlecove; LHS = Lamb's Head South; DC = Derreenacush; AB = Abbey Island

\begin{tabular}{l|c|cccccccccc} 
Site & CG & DN & LHN & CC & DN & LHS & LHN & DC & LHS & AB & AB \\
\hline Relevé sequence no. & 1 & 2 & 3 & 4 & 5 & 8 & 6 & 7 & 9 & 10 & 11 \\
Relevé no. (2020 survey) & & 6 & 4 & 7 & 5 & 1 & 3 & 8 & 2 & 9 & 10 \\
Quadrat size (m²) & 4 & 4 & 4 & 4 & 4 & 4 & 4 & 4 & 4 & 4 & 4 \\
Soil type: peat = p & $\mathrm{p}$ & $\mathrm{p}$ & $\mathrm{p}$ & $\mathrm{p}$ & $\mathrm{p}$ & $\mathrm{p}$ & $\mathrm{p}$ & $\mathrm{p}$ & $\mathrm{p}$ & $\mathrm{p}$ & $\mathrm{p}$ \\
Rock type (sds = sandstone) & sds & sds & sds & sds & sds & sds & sds & sds & sds & sds & sds \\
\% small shrub cover & 45 & 30 & 50 & 55 & 50 & 35 & 90 & 70 & 90 & 80 & 90 \\
\% grass cover & 20 & 20 & 5 & 15 & 20 & 10 & 3 & 10 & 5 & 26 & 30 \\
\% bryophyte cover & 1 & 19 & 15 & 15 & 0 & 30 & 0 & 10 & 0 & 0 & 0 \\
\% bare ground & 10 & 20 & 25 & 8 & 20 & 10 & 0 & 10 & 1 & 2 & 0 \\
\% bare rock & 30 & 10 & 10 & 15 & 18 & 0 & 0 & 5 & 0 & 0 & 1 \\
Dead Calluna \% cover & & 30 & & 2 & & 5 & & & & & \\
Veg height, mean of 5; cm & 30 & 21 & 8.1 & 14.6 & 28 & 33 & 23.2 & 14.2 & 31 & 22 & 12.6 \\
Soil depth, mean of 5; cm & 10 & 6 & 8 & 8.8 & 7.6 & 17.4 & $>30$ & 11.6 & 16 & 19 & 19 \\
Slope & 70 & 10 & 20 & 60 & 45 & 10 & 45 & 20 & 45 & 30 & 40 \\
Aspect & NE & $\mathrm{N}$ & $\mathrm{NW}$ & $\mathrm{W}$ & $\mathrm{S}$ & $\mathrm{SE}$ & $\mathrm{SE}$ & $\mathrm{N}$ & SW & NE & NE \\
Grazed & low & no & low & no & no & no & low & high & low & low & low \\
Burnt & low & low & no & low & low & low & no & low & low & no & no
\end{tabular}


Total no. Simethis

Total no. Simethis in fruit (fl) $\%$ tot. Simethis in fruit/fl

Simethis cover \%

Calluna vulgaris

Ulex gallii

Molinia caerulea

Simethis mattiazzii

Erica cinerea

Erica tetralix

Potentilla erecta

Carex panicea

Carex binervis

Pteridium aquilinum

Succisa pratensis

Jasione montana

Agrostis canina

Festuca vivipara

Agrostis capillaris

Carex pilulifera

Hypochaeris radicata

Polygala serpyllifolia

Sedum anglicum

Solidago virgaurea

Salix repens

Dactylorhiza maculata

Bryophytes and lichens

Dicranum scoparium

Frullania tamarisci

Hypnum jutlandicum

Campylopus introflexus

Campylopus flexuosus

Scapania gracilis

Diplophyllum albicans

Ceratodon purpureus

Cladonia cf portentosa

Cladonia sp. (Cladonia group)

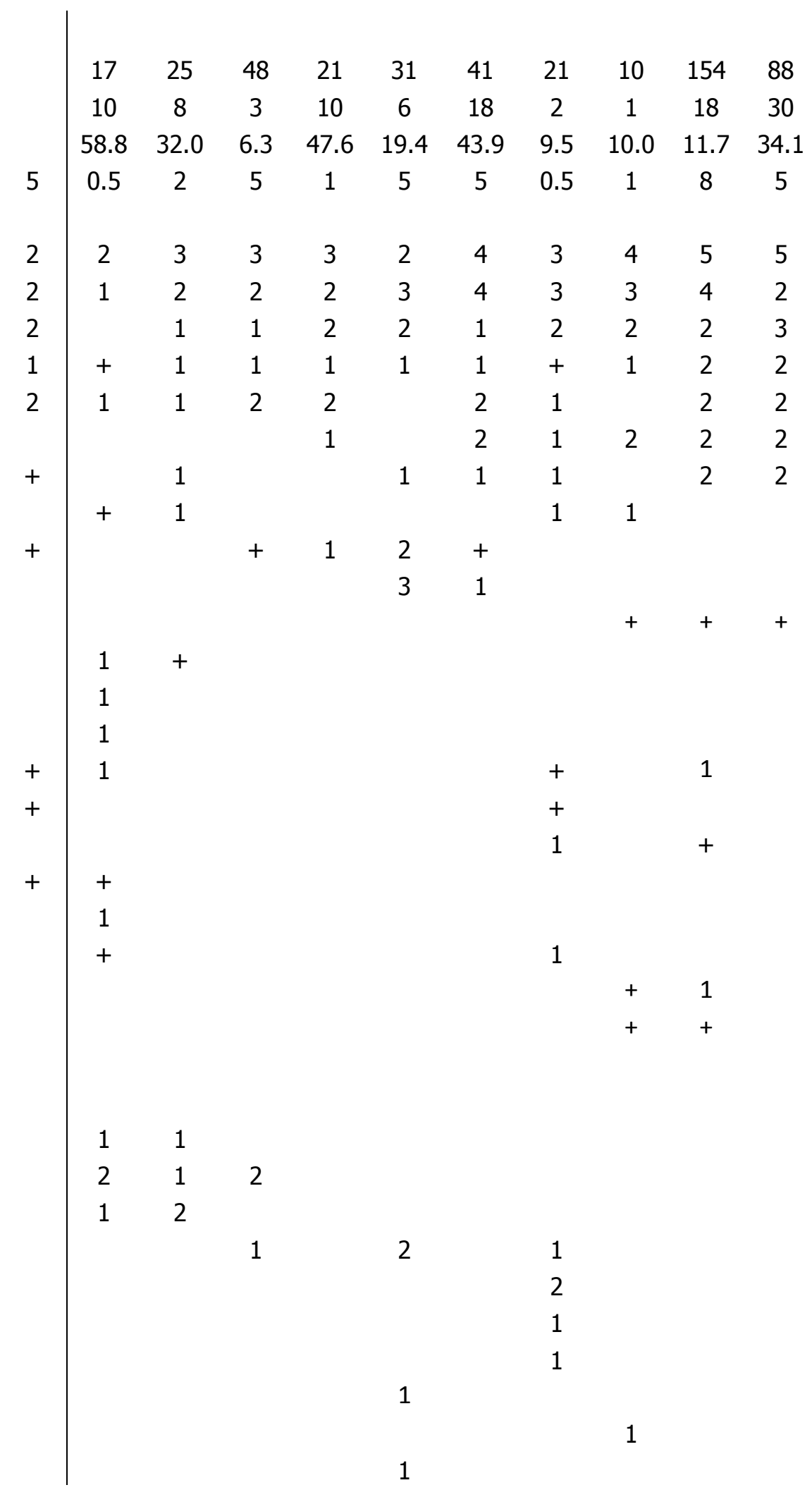

Species with cover-abundance of + and occurring in only one relevé: Relevé 2: Rubus fruticosus agg., Jacobea vulgaris, Viola riviniana; relevé 3: Danthonia decumbens, Leucobryum glaucum; relevé 8: 
Anthoxanthum odoratum, Holcus lanatus, Bryum sp.; relevé 9: Lysimachia tenella, Narthecium ossifragum, Trichophorum germanicum; relevé 10: Carex flacca, Juncus cf acutiflorus.

The number of individual plants per $4 \mathrm{~m}^{2}$ quadrat (Table 3) varied a lot and in some cases, was strikingly high, ranging from 10 in quadrat 2 at Lamb's Head South to 154 at Abbey Island (quadrat 9). The number of plants with flowers, or more often fruit (or bare stalks), also varied between sites. The numbers of each per quadrat were averaged where relevant and the percentage obtained for each site. Just over $50 \%$ of the plants at Derrynane had inflorescences, or their remains, whereas at Castlecove and Derreenacush these were less than $10 \%$. It is worth noting that, though the number of plants per quadrat on Abbey Island was much higher than at the other sites, the percentage of plants with inflorescences was relatively low. In many cases a lot of the fruit were missing from the spikes; some had not formed fully, some may have been eaten or dropped off prematurely, even in July (NB in September, it was still possible to find all the flowering stalks, as they were still green and had not shrivelled). Therefore, the percentage of plants with flowering spikes is a slight overestimate of their reproductive potential.

Table 3. Demographics and reproductive potential of Simethis mattiazzii at the six sites, recorded in July (\& September; Abbey Is.) 2020. CC = Castlecove, DC = Derreenacush (1 relevé each). Quadrats are all $4 \mathbf{~ m}^{2}$. Infls $=$ inflorescences

\begin{tabular}{|l|c|c|c|c|c|c|c|c|c|c|c|c|c|c|}
\hline & \multicolumn{4}{|c|}{ Lamb's Head S } & \multicolumn{3}{c|}{ Lamb's Head N } & \multicolumn{3}{c|}{ Derrynane } & \multicolumn{2}{c|}{ CC } & DC & \multicolumn{3}{c}{ Abbey Island } \\
\hline Quadrat no. & 1 & 2 & mean & 3 & 4 & mean & 5 & 6 & mean & 7 & 8 & 9 & 10 & mean \\
\hline No. Simethis plants & 31 & 10 & $\mathbf{2 0 . 5}$ & 41 & 25 & $\mathbf{3 3}$ & 21 & 17 & $\mathbf{1 9}$ & 48 & 21 & 154 & 88 & $\mathbf{1 2 1}$ \\
\hline No. with infls & 6 & 1 & $\mathbf{3 . 5}$ & 18 & 8 & $\mathbf{1 3}$ & 10 & 10 & $\mathbf{1 0}$ & 3 & 2 & 18 & 30 & $\mathbf{2 4}$ \\
\hline \% with infls & & & $\mathbf{1 7 . 1}$ & & & $\mathbf{3 9 . 4}$ & & & $\mathbf{5 2 . 6}$ & 6.3 & 9.5 & & & $\mathbf{1 9 . 8}$ \\
\hline
\end{tabular}

In 2009, plants and inflorescences were counted for each $1 \mathrm{~m}^{2}$ quadrat and averaged per site, so for comparison these numbers were expressed per $4 \mathrm{~m}^{2}$ (Table 4 ). The mean number of plants per $4 \mathrm{~m}^{2}$ in 2009 varied greatly between sites, though the range $(13.2-58.4)$ was lower than in 2020 (19-121, mean values only). Since in 2020 the number of plants with inflorescences in a quadrat was counted, whereas in 2009 inflorescences were counted per quadrat, these data are not strictly comparable, but it would appear that, at least on Abbey Island, many more inflorescences per $4 \mathrm{~m}^{2}$ were found in 2020. It is worth comparing the 2009 data for a fenced-off part of Abbey Island ('ungrazed' Table 4) with the adjacent area grazed (at low intensity) by cattle. The mean number of plants per $\mathrm{m}^{2}$ was almost two-thirds greater in the grazed quadrats than in ungrazed, but there was little difference in the number of inflorescences produced per quadrat between grazed and ungrazed sites. 
Table 4. Mean plant census per quadrat $(n=10)$ sampled in 2009. Infls $=$ inflorescences

\begin{tabular}{|c|c|c|c|c|}
\hline Metapopulation/ site & $\begin{array}{l}\text { Mean no. } \\
\text { plants } \mathbf{~ m}^{-2} \\
\text { quadrat }\end{array}$ & $\begin{array}{l}\text { Mean no. } \\
\text { plants } 4 \mathbf{m}^{-2}\end{array}$ & $\begin{array}{l}\text { Mean no. } \\
\text { infls } \mathbf{~ m}^{-2} \\
\text { quadrat }\end{array}$ & $\begin{array}{l}\text { Mean no. } \\
\text { infls } 4 \mathrm{~m}^{-2}\end{array}$ \\
\hline Derrynane & 6.6 & 26.6 & 3.2 & 12.7 \\
\hline Castlecove & 4.1 & 16.4 & 2.6 & 10.5 \\
\hline Abbey Island ungrazed & 5.8 & 23.2 & 2.9 & 11.5 \\
\hline Abbey Island grazed & 14.6 & 58.4 & 2.7 & 10.7 \\
\hline Lamb's Head & 6.6 & 26.4 & 2.1 & 8.5 \\
\hline Beara Peninsula & 3.3 & 13.2 & 2.3 & 9.1 \\
\hline
\end{tabular}

\section{Pressures and threats}

The data in Tables $3 \& 4$ give some insight regarding site management required to keep a healthy $S$. mattiazzii population that can also reproduce sufficiently to maintain the population. Whereas on Abbey Island the grazed site in 2009 had many more S. mattiazzii plants, it is notable that a lower percentage of these produced flowering spikes. This suggests that grazing during the flowering time may not be advisable, but that grazing is, nonetheless, important. It is of concern that $S$. mattiazzii in at least two of the sites visited in 2020 (Derreenacush and Castlecove) would appear to have a much-reduced reproductive capacity as, though the numbers per quadrat were quite high, very few had managed to flower. Many sites have deteriorated since 2009. The most notable extremes in management seen in 2020 were on the one hand, the results of an extensive severe fire in 2019 on Lamb's Head (Fig. 9) and on the other, the gradual growing-over of the vegetation through lack of grazing, rendering parts of Derrynane Harbour and Castlecove (already ungrazed in 2009) sites inaccessible (Fig. 10). The grazing intensity appears now to be reduced to near zero at Derrynane, which is not fenced, but where stock access is difficult, and was low on Abbey Island, such that human access was difficult and, aside from one small plant in deep furze, the species was not found in the northern part of the island, possibly because it is no longer successfully competing with the low shrubs even on the ridges. This includes the ridges with relatively low vegetation in the fenced-off section, where the species had been recorded as recently as 2014 (Duff \& Wilson, 2014). The Lamb's Head South site is easily accessible by sheep but at Lamb's Head North grazing is low and only barely adequate at the relevé sites (Fig. 8). Across a fence-line to the north-west of these, tall vegetation, presumably as a result of little or no grazing, may be the reason why the species was not found nearer the coast at that site in 2020. As the fire around the south of Lamb's Head had removed even the underlying peat in many places (Fig. 9, image on left), it was hard to assess whether grazing was controlling the vegetation in July 2020, but, where $S$. mattiazzii plants had survived, they benefited from the bare ground where it was abundant (Fig. 9, image on right). The Dereenacush site on the Beara peninsula was heavily grazed by cattle both in 2009 and 2020 and this is likely to have had a negative effect on the $S$. mattiazzii population there. The Cahergarriff site is grazed by sheep and has been 
burnt in the past; Rhododendron ponticum encroachment is a current threat (Hodd, 2020), as it is in Derrynane.
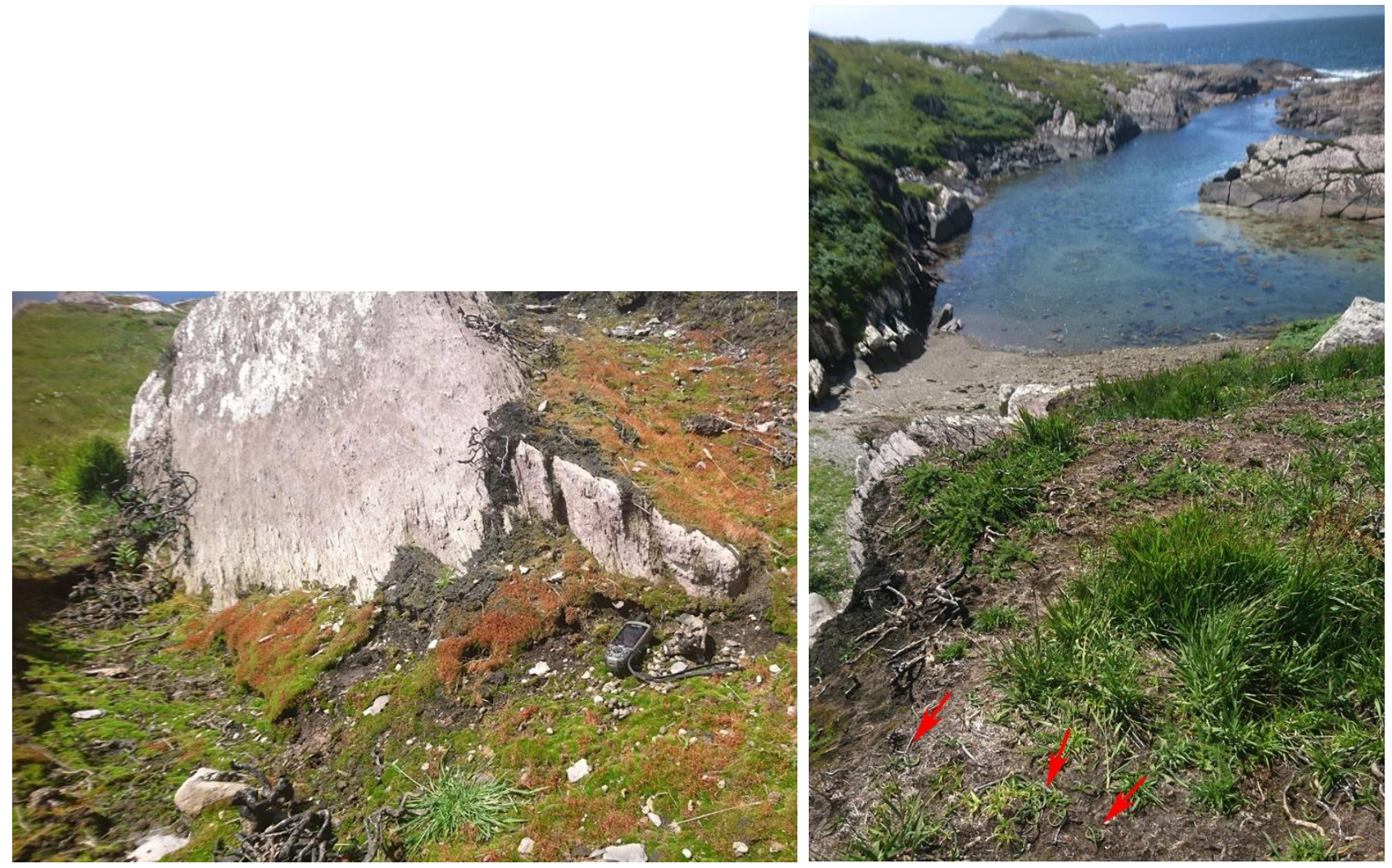

Figure 9. Left: Burnt area on sandstone ridge, Lamb's Head South, where Simethis mattiazzii was recorded in 2009 (mostly covered in the moss Funaria hygrometrica with abundant rust-brown capsules). Right: Top of cliff facing SW and overlooking cove (with quay to right of photo) at Lamb's Head South in region where most S. mattiazzii plants were found on 6.7.2020. Relevé 1 was taken near this spot. Note burnt Calluna twigs. Some of the $S$. mattiazzii plant clusters are indicated by arrows. Images taken 6.7.2020

\section{Plant population variation}

Measurements taken in 2009 of the mean number of flowers, leaf length, seed capsule numbers and mean height of plants across the entire group of populations revealed a homogeneous community with only minor morphological differences between the five metapopulations (Lupton, 2009).

Genetic diversity of sub-populations

DNA was extracted from 126 individuals (25 individuals each from metapopulations at Derrynane Harbour, Castlecove, Abbey Island, and Derreenacush and 26 individuals from Lamb's Head). The DNA was clean and of high quality (Lupton, 2009). To assess genetic diversity, specific chloroplast and nuclear gene regions were targeted (Table 5) to check for differences in the sequences across a subset of the 126 genetic samples. In total, 21 non- 
coding DNA regions were examined for genetic variation and 17 chloroplast and 4 nuclear regions also examined. Eight of the regions amplified successfully and produced clean, high quality DNA sequences. No genetic variation was detected in these regions. No variation was detected in the 21 gene regions screened.

Table 5. Results for the molecular investigation of 21 non-coding DNA regions. Primer sequences for each region can be found in Kress et al. (2005), Shaw et al. (2005) and Shaw et al. (2007)

\begin{tabular}{|c|c|c|c|c|c|}
\hline Name of region & $\begin{array}{c}\text { Type of } \\
\text { DNA }\end{array}$ & PCR & $\begin{array}{c}\text { DNA } \\
\text { sequence }\end{array}$ & $\begin{array}{l}\text { Region- } \\
\text { length in } \\
\text { bas epairs }\end{array}$ & Heterogeneity \\
\hline $\operatorname{trnT}-\operatorname{trnF}$ & chloroplast & amplified & high quality & 904 & invariable \\
\hline psbA-trnH & chloroplast & amplified & high quality & 668 & invariable \\
\hline $\operatorname{trnD}-\operatorname{trn} T$ & chloroplast & amplified & high quality & 760 & invariable \\
\hline atpL-atpH & chloroplast & amplified & high quality & 623 & invariable \\
\hline 3'rpS16-5'trnK & chloroplast & amplified & high quality & 818 & invariable \\
\hline psbD-trnT & chloroplast & amplified & high quality & 940 & invariable \\
\hline psbJ-petA & chloroplast & amplified & high quality & 855 & invariable \\
\hline $\operatorname{trnS}$-trnFM & chloroplast & amplified & high quality & 937 & invariable \\
\hline rpoC & chloroplast & did not amplify & N/A & _- & _- \\
\hline matK & chloroplast & did not amplify & N/A & _ & _ \\
\hline $\operatorname{trnC}{ }^{\mathrm{GCA}} \mathrm{R}-\mathrm{rpoB}$ & chloroplast & did not amplify & N/A & - & - \\
\hline $\operatorname{trn} \mathrm{V}^{\mathrm{UAC}} \mathrm{x} 2-\mathrm{ndhC}$ & chloroplast & did not amplify & N/A & - & - \\
\hline ndhF-rpL32R & chloroplast & did not amplify & N/A & _ & - \\
\hline rbcL1 & chloroplast & did not amplify & N/A & - & - \\
\hline rbcL-a & chloroplast & did not amplify & N/A & - & - \\
\hline trnL-rpL32F & chloroplast & did not amplify & N/A & - & - \\
\hline trnQ-5'rpS16 & chloroplast & did not amplify & N/A & - & - \\
\hline $\begin{array}{l}\text { ITS4+ITS5 } \\
\text { forward }\end{array}$ & nuclear & amplified & poor quality & N/A & N/A \\
\hline $\begin{array}{c}\text { ITS4+ITS5 } \\
\text { reverse }\end{array}$ & nuclear & amplified & poor quality & N/A & N/A \\
\hline ITS1 & nuclear & did not amplify & N/A & - & _- \\
\hline ITS2 & nuclear & did not amplify & N/A & - & - \\
\hline
\end{tabular}




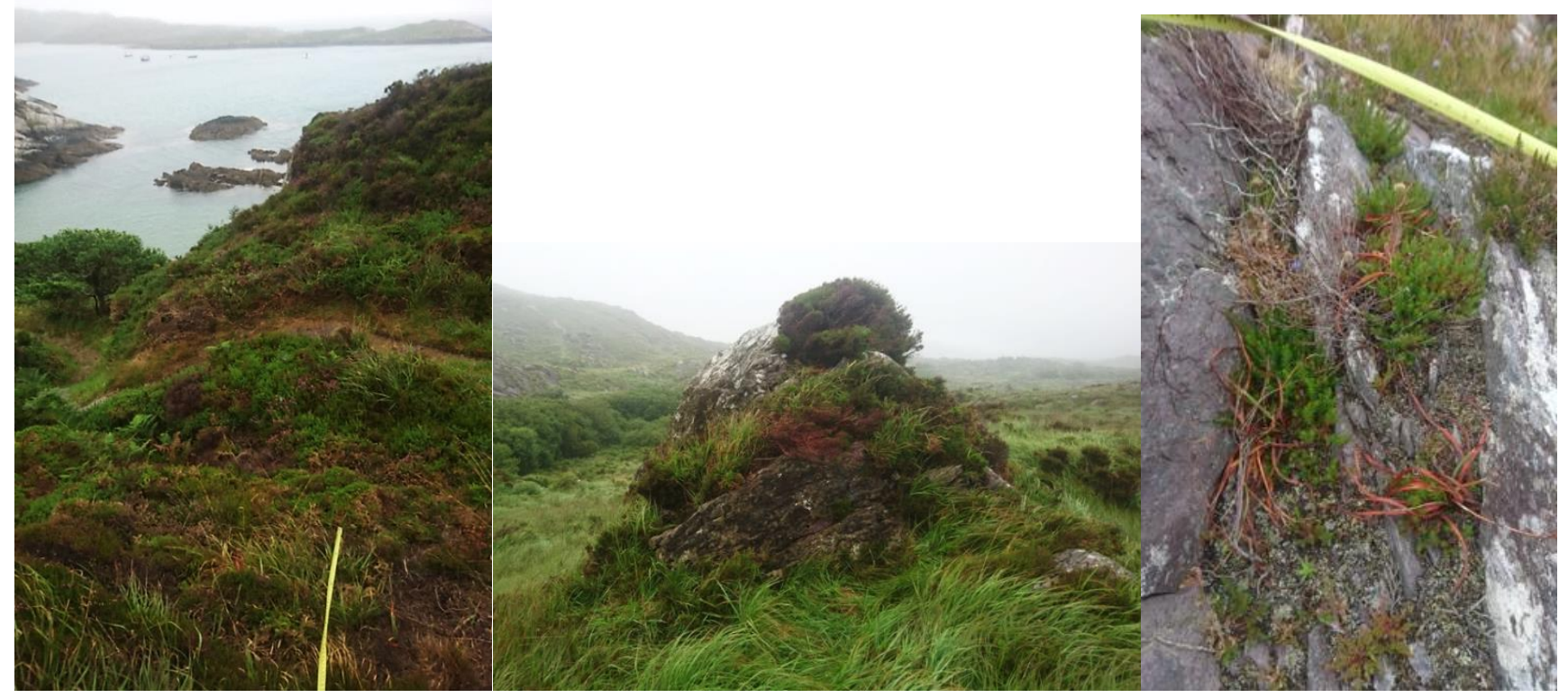

Figure 10. Left: Quadrat 5 (c. $1 \mathrm{~m}$ of yellow tape-measure visible) overlooking small cove to west of Derrynane Bay (see Fig. 6). The Kerry Way track is below the quadrat in middle of photo. Note dense shrubby Calluna and Ulex gallii and patches of wind-burn. Centre: Site of quadrat 7 west of Castlecove, with tall Calluna on rock and dense Molinia below the ridge. Right: Simethis plants, already withering to a characteristic orange-brown, clustered around the edge of the dense herbage on western face of sandstone ridge facing camera in central photo. Images taken 7.7.2020

\section{Discussion}

Distribution, ecology and reproductive ecology of Simethis mattiazzii in Ireland

The distribution of $S$. mattiazzii in Ireland is strikingly limited. It is confined to the southwestern end of the Iveragh Peninsula in S Kerry, with two outlying populations on the Beara Peninsula to the south. Where it occurs on these peninsulas, it has a high abundance and would therefore seem to reproduce well, probably by seed. In S Kerry, there appear to be two patterns within its distribution; a cluster of four populations around Derrynane Bay and a more extensive area in the Castlecove and Glanlough region. In no case has the species been seen further than two kilometres from the coast and it is almost always found on sandstone ridges, which provide bare, shallow peat soils adjacent to exposed rock, for seed establishment. This results in clusters of plants being scattered across a region, effectively found on the often contiguous 'islands' of sandstone ridges and may account for the localised populations encountered, especially around Derrynane Bay.

Within sites, the clustered nature of the plants seen in 2020 was striking. Where it was found, there were $50->150$ plants in a small area $\left(c .5-6 \mathrm{~m}^{2}\right)$, but often none within a further $50 \mathrm{~m}$. This suggests that the seed is mostly shed near the parent, where it benefits from any bare soil to germinate. The capsule dehisces late in the season (Kubitsky, 1998) and the seeds are relatively large (c.4 mm; Webb, 1980) and heavy (c.4 mg; Calvino-Cancela \& Rubido-Bará, 2012), so long-range dispersal is probably rare. The germination rate of 1000 seeds from 150 plants collected in Kerry in August 1995 was tested; after 109 days under 
$25 / 20^{\circ} \mathrm{C} 13 \mathrm{hrs}$ light/11 hrs dark hour cycle, no germination was recorded (Martin, 1998). Seeds were not treated prior to sowing, so it is conceivable that the hard seed coat of $S$. mattiazzi (Calvino-Cancela \& Rubido-Bará, 2012) requires pre-treatment for germination to occur. Testing the effect of seed passage through slugs on the germination rates of nine plant species, Calvino-Cancela \& Rubido-Bará (2012) reported no germination of 'slug processed' or control seeds for $S$. mattiazzii, whereas all other tested seeds germinated. Further germination trials, including pre-treatments and temperature variations are required to understand this important element of the species lifecycle.

No data were found relating to the pollination requirements of the species; however, its open, simple floral structure suggests that it is visited by a number of pollinator species. One Bumblebee (Bombus lucorum) and a Hoverfly (genus Eristalis) were seen foraging on several specimens of $S$. mattiazzii during the 2009 field work. Field observations in Portugal suggest that, despite a low rate of seed set in a bad season (2020), the species rarely if ever reproduces vegetatively, since it is anchored by a very short, vertical rhizome (D. Holyoak, pers. comm.).

The vegetation in which $S$. mattiazzii occurs at these sites is dominated by heathers and the low-growing Ulex gallii. The presence of Molinia caerulea indicates that the heath is wet, but the extreme slopes where many of the populations occur, ensure that the shallow peats are well-drained. In all sites recorded, the presence of other grasses such as Agrostis capillaris and $A$. canina, were rare. However, the higher abundance of Molinia and of Schoenus nigricans recorded in two quadrats from Abbey Island in 1998 (Bleasdale \& Conaghan, 1998) would suggest that the species also occurs in slightly wetter soils. This vegetation, with the presence of $U$. gallii, is a coastal variant of EU Habitats Directive 4030 Dry Heath, which is widespread in Ireland, especially in the south and west (NPWS, 2019).

\section{Genetic homogeneity in Ireland}

The genetic evidence shows the five populations analysed to be extremely homogeneous and therefore it appears that these populations of $S$. mattiazzii in Ireland exist as one large single population, possibly made up of $5-6$ meta-populations. Hickey (2012) tested 13 RAPD (Random Amplified Polymorphic DNA) and 12 chloroplast loci in a small number of Irish and Spanish (Seville and Salamanca) samples. The RAPD showed some variation in the Irish sample but was considered unreliable; overall results were inconclusive, perhaps partly as the sample size was very small. Of the eight chloroplast loci used, only one was variable and was present in the Irish and Seville populations but absent from the Salamanca sample. However, these results could not be replicated and therefore further research is required.

Genetic uniformity can be common in newly introduced, founder-populations, that is, populations derived from one or two individuals. Colonisation often involves severe founder effects, which have an important genetic impact (Barrett \& Husband, 1990). Particularly in the case of anthropogenic introductions into new areas, species populations are often founded from only a few individuals that are completely isolated from the source population and thus go through a period of substantial genetic drift (Parisod et al., 2005).

If the founder population contains only a few individuals, is genetically depauperate and remains small, the effects of loss of diversity will be pronounced due to potential random genetic drift or inbreeding depression, for example. On the other hand, if there have been 
multiple introduction events followed by a rapid expansion, effects may be minimal (McBreen \& Cruzan, 2004). The genetic and morphological uniformity and limited expansion of the Irish populations of $S$. mattiazzii suggest that these effects are pronounced, supporting the probability of a single, or limited number of recent introduction events. Further refinement of the tentative results obtained by Hickey (2012) using the SNP (single nucleotide polymorphisms) chloroplast marker $p s b J$ - petA would be a prudent next step. Comparison with the genetics of a range of continental populations using newer techniques would also give perspective to these results.

\section{S. mattiazzii occurrence and ecology in continental Europe}

Outside Ireland, S. mattiazzii is found in France mainly in the south-west, in heaths and pinewoods (https://www.tela-botanica.org/bdtfx-nn-64458-synthese; Dupont, 2015) and in moderately humid scrub and Molinia meadows (Tison \& de Foucault 2014). Its Mediterranean distribution is confined to acidic coastal rocks in French Provence and it occurs sporadically and locally in western Italy; it is found also in scrub forest in the lowlands and foothills of the north African coast eastwards to Tunisia (Maire, 1958, Gianguzzi et al., 2012; Dupont, 2015) (Fig. 2). Described in Flora Europaea (Webb, 1980) as occurring in heaths, rocky ground and open pinewoods, its essentially western distribution suggests a requirement for humid soils. This requirement is picked up by Gianguzzi et al. (2012) who note that even in Sicily, its location is subject to relatively damp 'oceanic' conditions.

On the Iberian Peninsula, the species has a predominantly Atlantic and northern distribution, associated with heathlands (Martínez Ortega, 2014; Araújo et al., (2020) http://www.anthos.es), where it is chiefly found in heather (Calluna vulgaris, Erica species), gorse (Ulex species) or low Cistus heathlands, as well as in damp pastures and woodland clearings, generally on acid soils (Martínez Ortega, 2014). In Galicia, in the region of La Coruña, it grows in low gorse heath (tojal) on mineral soils (Fagúndez Díaz, 2011). It has also been seen by the second author in low, open heath with several Hiberno-Lusitanian heathers as well as U. gallii in Asturias, on the north coast of Spain (Fig. 11).

Aside from Sicily, where it grows on limestone rocks, its occurrence seems to be mostly on acid, sometimes peaty soils. The moderately dry peaty soils over sandstone on mostly south-facing sites in SW Ireland - where there is a relative absence of winter frosts - would seem to provide very similar, if cooler, conditions to those at least of the western continental sites.

\section{Potential origins of the Irish Simethis mattiazzii populations}

It is highly unlikely that $S$. mattiazzii, a small monocot mostly of mild climatic lowland areas, survived the Last Glacial Maximum in Ireland - if indeed it was ever present (Godwin, 1975) and therefore to be considered a native species, it would have to have migrated back north to Ireland from a refugium, possibly in Spain or at best south-west France. As it occurs only sporadically north of Nantes (Dupont, 2015), it is difficult to formulate a migration route whereby it colonised just a few locations on two peninsulas in SW Ireland and nowhere in Britain. The populations in Cork and Kerry are over $500 \mathrm{~km}$ from their nearest occurrence in Brittany (Webb, 1983). 


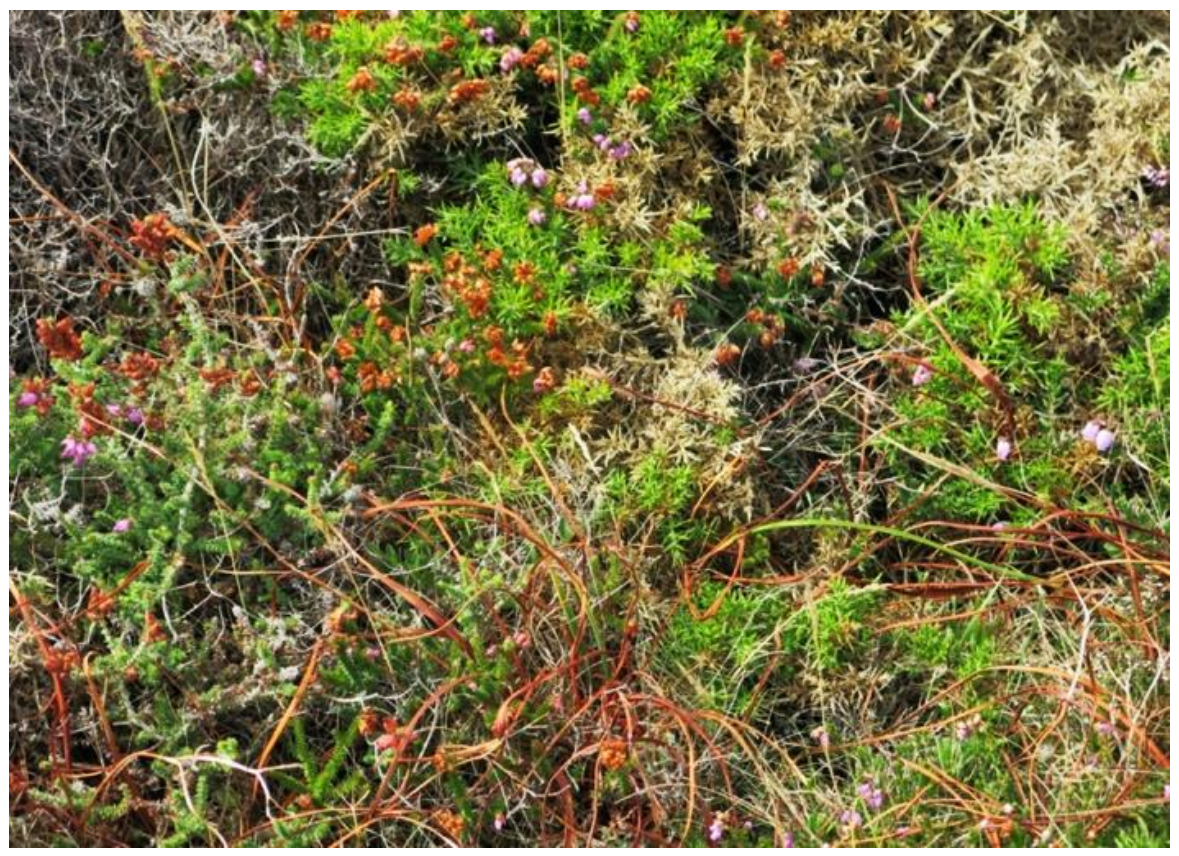

Figure 11. Simethis mattiazzif late in season (22.8.2015) with typical orange-coloured leaves on Cabo Peñas, Asturias, N Spain with low shrubs, Erica ciliaris (faded, upper left), E. mackayana, Daboecia cantabrica (right) and Ulex gallii

The highly localised distribution of $S$. mattiazzii, given the abundance of dry coastal heath throughout Ireland, especially in the south and west (NPWS, 2019), is also unusual, especially given its ability to reproduce where it occurs. Its location particularly at the entrance to Derrynane Bay, has led to the suggestion that it might have been brought in with smuggled goods, since Derrynane was particularly active for smugglers in former times (Wyse Jackson, 1984; Kelleher et al., 2019). Pearman \& Edgington (2016) make a cryptic remark that the species' 'claim to be native in Britain and Ireland is debatable' yet provide no evidence to support this in the case of the Irish populations. To date, the accepted view is that the species is native to Ireland (Scully, 1916; Praeger, 1934; Webb, 1983; Parnell \& Curtis, 2012).

However, there are several Hiberno-Lusitanian heathers, also absent from Britain, with disjunct distributions in Europe, as well as within Ireland, that grow in damp heaths alongside S. mattiazzii especially in northern Spain (Fig. 11). The native status in Ireland of two, Erica mackayana and $E$. erigena has already been queried. Erica mackayana only occurs in four localised regions in Ireland and elsewhere only in northern Spain and, based on its biology and location in Ireland, it is thought that it was brought in as packing with smuggled goods from $\mathrm{N}$ Spain (Sheehy Skeffington \& Van Doorslaer, 2015; Sheehy Skeffington, 2017). Erica erigena in Ireland is confined almost entirely to small coastal rivers and lakes in western Mayo and is frequent in NW Spain and some of the Portuguese coast. Foss \& Doyle (1988) suggest it was brought back by pilgrims from Santiago de Compostela in Galicia, again possibly as packing or from animal bedding. A third heather, this time common in SW England, E. ciliaris, only occurs in Ireland as less than a dozen plants in Roundstone Bog, Connemara, beside a small road and it is now considered not to be native to Ireland (Curtis, 2000). 
Since $S$. mattiazzii grows through clumps of heather and gorse, it is quite possible that it was also brought from north Spain to Ireland as an inadvertent component of packing for goods. Heather and Bracken Pteridium aquilinum are still harvested as bedding for animals in Galicia (Sheehy Skeffington, 2017) and this material was seen in the 1980s as packing in a boat in a Galician port (P. Foss, pers. comm.). Indeed 'twig material and finer, more moss/heather-like material' has been found as dunnage (packing material) in a wreck off Donegal (C. Kelleher, pers. comm.). If similar material, taken from near one of the western Portuguese, Spanish, or French ports, was used to transport more fragile goods such as wines or brandy and S. mattiazzii seed was caught up in the material, it could well have come ashore with the goods and their packing.

The homogeneity of the genetic composition, as so far established, would suggest that the species was brought perhaps with a single cargo possibly from SW France or N Spain and off-loaded to a number of hidden locations around Kenmare Bay.

The O'Connell family of Derrynane was renowned for its smuggling activity (MacDonagh, 1903; MacDonagh, 1988). There are records of tea and brandy being sent to Derrynane from Nantes and occasionally from Bordeaux, as well as the odd hogshead of wine for personal consumption (Cullen, 1969; 2000). The O'Connells were also known to import smuggled goods from Spain (Kelleher et al., 2019). This was in the late $18^{\text {th }}$ and early $19^{\text {th }}$ centuries and the intricate rocky nature of the coast of SW Kerry was renowned as dangerous to revenue patrol boats and their cutters dare not follow the lighter vessels 'gliding safely between the treacherous ridges' into the hidden coves (MacDonagh, 1903). A description (Maxwell, 1832) of a cutter appearing in Achill Sound in the 1820s and the appearance of rowboats 'from every nook and inlet' to collect and ferry away the 'illicit cargo' could well describe activities in Kenmare Bay. Cargo may have been off-loaded onto lands either side of Derrynane Bay, where $S$. mattiazzii is now abundant. If the genetics conclusively show that the populations are from a single introduction event, the ship may have been loaded onto boats disappearing into coves further up the Kerry side of Kenmare Bay, as well as onto Kilcatherine Point, at Derreenacush.

The extensive occurrence of $S$. mattiazzii east of Caherdaniel along, and within 1-2 km of, the coast would also suggest this. Detailed mapping would ascertain if this were one continuous population, or also several discrete clusters, possibly associated with small coves which occur along that coast, many partially hidden from the open sea by small offshore islands (Fig. 7). The occurrence of the species at Derreenacush in West Cork is just across Kenmare Bay from Derrynane and is along a track that leads from a tiny cove accessible only at high tide through a sea arch (Fig. 12). This strongly suggests that it has been somehow transported there by sea and that the aim was to conceal the cargo from view at sea. The Cahergarriff population, on the south side of the Beara Peninsula, is on a main road, even in 1845 , and is not connected to Kenmare Bay, so may have been brought overland, or as a separate delivery to the inner bay behind Bere Island. Though more detailed records now exist since Scully's time, the overall distribution of $S$. mattiazzii is not dissimilar to that described by him for Kerry (Scully, 1916), suggesting it has not spread far in the intervening century. This may indicate that it is a relatively recent adventive to Ireland and/or that dispersal is slow from the points of arrival. Land-use changes in recent decades have unfortunately contributed to its decline locally. 
One observation may support the idea that $S$. mattiazzii is easily transported around coasts and deposited on land, through human traffic and trade. The details of occurrence of $S$. mattiazzii in the Mediterranean as outlined by Gianguzzi et al. (2012) are striking in that the sites are not only very coastal, but many occur on small islands off the coasts of especially Corsica, Sardinia, Sicily and mainland Italy (Fig. 2). Its requirement for humid conditions in an otherwise dry climate (Maire, 1958) might explain this concentration on more maritime sites, but the pattern also fits as far back as that of Phoenician trading routes and ports, from c. 1100 BC, that extended as far as Cádiz in south-western Iberia and later even further north along the western Iberian coast (Aubet, 2001). It is not inconceivable, therefore, that some of the small and marginal populations of $S$. mattiazzii in the Mediterranean were also established through trade and transport of goods over the centuries from regions where the plant is more abundant.

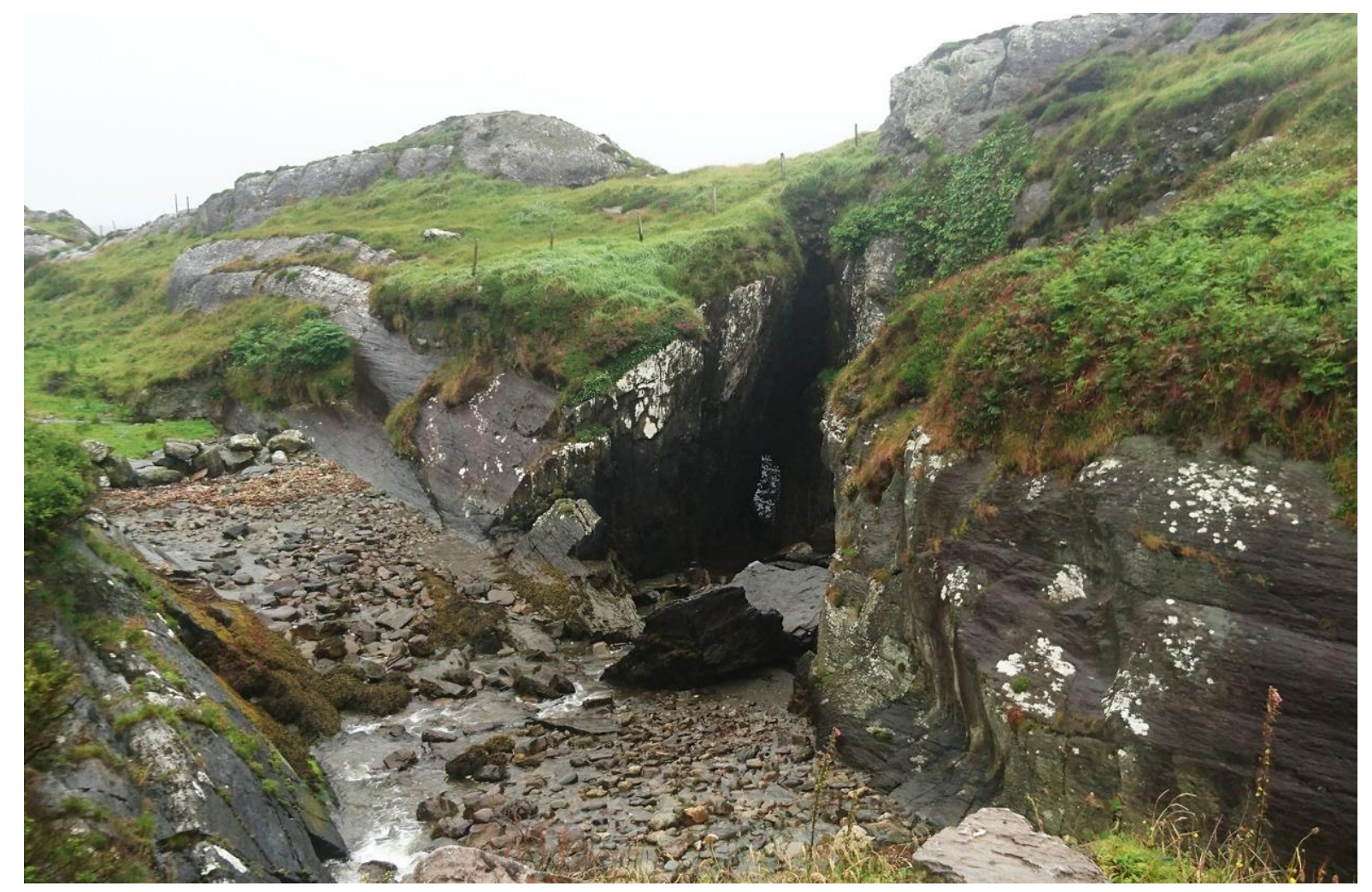

Figure 12. Hidden cove at Derreenacush, $W$ Cork at low tide. The sea enters through the arch at high tide. This is $<\mathbf{2 0 0} \mathbf{m}$ from the $S$. mattiazzii site on the hill behind and left of the photo image.

\section{Conservation of Simethis mattiazzii in Ireland}

The greatest concentration recorded of the species is around Derrynane Bay, with Abbey Island supporting the highest number of flowering plants. The plant community associated with S. mattiazzii in Ireland, 4030 Dry Heath, is a relatively common habitat type in Ireland found frequently on mountainsides and low-lying coastal areas. However, the status of this habitat is thought to be less favourable than in previous decades (NPWS, 2019) and our 
observations lead us to conclude that this is due in part at least, to a marked decrease in grazing in the South Kerry coastal region. The Derrynane and Glanlough (east of Castlecove) areas in S Kerry are within the Kenmare River SAC (https://www.npws.ie/maps-and-data; accessed 15.8.2020) and as such, would require active measures to encourage landowners to restore much-needed extensive grazing where this has been discontinued. As with many seminatural habitats in Ireland, managed grazing is essential to the maintenance of a balanced ecosystem. Unmanaged grazing, including grazing at the wrong time of the year or high stocking densities can eliminate species, and rare plants are particularly vulnerable since they are often sensitive to slight changes in their habitat or community structure. Though fire has been listed as a threat especially in the Lamb's Head area (Curtis \& McGough, 1988) and is a destructive management tool, even in heathland, it is worth noting that $S$. mattiazzii is a ready coloniser after fire in open forests in La Mancha, northern Spain (Morales del Molino \& Mateo, 2010). However, we would encourage the maintenance of low intensity farming in south-west Ireland, with year-round grazing by sheep or, where cattle are grazed, we suggest a shorter, autumn to spring grazing regime at a density sufficient to keep Molinia as well as heathers in check.

\section{Acknowledgements}

The authors are grateful to a great number of people for supplying help, advice and information. Many thanks to Anke Dietzsch and Caroline Nienhuis for collecting population data and undertaking the genetic research in 2009 and to Colin Kelleher for his help and advice with the genetic analyses. Clare Heardman, Mike O'Sullivan and Rosemary FitzGerald were generous with information about local populations and land management histories. Mike Wyse Jackson was very helpful in supplying much new database information. Vice-County Recorders Caroline Mhic Daeid and Rory Hodd gave local interpretations and data-base information; Rory was also invaluable in confirming and identifying the bryophytes. Andy Bleasdale, Mary Cockerill, John Conaghan, Graham Day and Ian Denholm kindly helped consolidate plant records. Nick Scott advised on and drew some of the maps, helped in the field and gave enthusiastic suggestions, especially regarding the history of the arrival of $S$. mattiazzii in Ireland. David Holyoak was most helpful in supplying information on S. mattiazzii ecology and distribution in Portugal and Elisabeth de Faÿ advised on French distribution maps. Connie Kelleher was very helpful in giving information on the local history and shipping stories, as well as providing references. Thanks to Chris O'Neill and James O'Shea for information and to Brian Crowley who supplied literature on the O'Connells of Derrynane and information on smuggling. Jody Moylan gave information on the O'Connell family and local smuggling activities and access to useful references. Jaime Fagúndez Díaz kindly commented on an early draft of the MS and thanks are also due to Martin Sanford for his comments. The authors would like to thank The Heritage Council for supporting the work undertaken in 2009 and the National Parks and Wildlife Service for permission to include Cahergarriff data in Table 1 and the first relevé in Table 2. We are grateful to landowners who granted access to their land where requested.

\section{References}

Aubet, M. E. 2001. The Phoenicians and the West. Politics, Colonies and Trade. $2^{\text {nd }}$ ed. Cambridge: Cambridge University Press. 
Araújo, P. V., Almeida, J. D., Carapeto, A., Clamote, F., Lourenço, J., Porto, M., Pereira, A. J., Holyoak, D. T., et al. 2020. Simethis mattiazzi (Vand.) Sacc. - mapa de distribuição. Flora-On: Flora de Portugal Interactiva, Sociedade Portuguesa de Botânica. http://www.flora-on.pt/\#wSimethis+mattiazzi. Accessed on 23/06/2020.

Barrett, S. C. H. \& Husband, B. C. 1990. The genetics of plant migration and colonization. In: Brown, A. H. D.; Clegg, M. T.; Kahler, A. L.; Weir, B. S., eds. Plant population genetics, breeding, and genetic resources: 254-277. Sunderland, Massachusetts: Sinauer Association.

Bleasdale, A. \& Conaghan, J. 1998. A Baseline Vegetation Survey of Derrynane National Historic Park. Unpublished report. Dublin: National Parks \& Wildlife Service, Department of Arts, Heritage \& Gaeltacht.

Borrer, W., Babington, C. C., Berkeley, M. J., Wilson, W. and Other Eminent Botanists. 1849. Supplement to the English Flora of the late Sir J. E. Smith and Mr Sowerby. The Descriptions, Synonyms and Places of Growth. London: Salter.

Cabezudo, B., Talavera, S., Blanca, G., Salazar, C., Cueto, M., Valdéz, B., Hernández Bermejo, J. E., Herrera, C. M., Rodriguez Hiraldo, C. \& Navas, D. 2005. Lista roja de la flora vascular de Andalucía. Sevilla: Consejería de Medio Ambiente. Junta de Andalucía.

Calvino-Cancela, M. \& Rubido-Bará, M. 2012. Effects of seed passage through slugs on germination. Plant Ecology 213: 663-673. 10.1007/s11258-012-0030-8.

Cullen, L. 1969. The smuggling trade in Ireland in the eighteenth century. Proceedings of the Royal Irish Academy C 67: 149-175.

Cullen, L. 2000. The Irish Brandy-Houses of Eighteenth-Century France. Dublin: Lilliput Press.

Curtis, T. G. F. 2000. The change in the legal status of Erica ciliaris L. Dorset heath in Ireland. Yearbook of the Heather Society 2000: 89-92.

Curtis, T. G. F. \& McGough, H. N. 1988. The Irish Red Data Book 1. Vascular Plants. Dublin: Wildlife Service, Office of Public Works.

Duff, K. \& Wilson, F. 2014. Derrynane National Historic Park. Dune Grassland Habitat Survey and Management Recommendations. Final report for the Office of Public Works, Killarney, Co. Kerry.

Dupont, P. 1962. La flore Atlantique Européenne. Introduction à l'étude du secteur IbéroAtlantique. Documents pour les cartes des productions végétales. Série EuropeAtlantique. Vol. I. Toulouse. Faculté des Sciences.

Dupont, P. 2015. Les Plantes Vasculaires Atlantiques, les Pyrénéo-Cantabriques et les Éléments Floristiques Voisins dans la Péninsule Ibérique et en France. Jarnac: Société Botanique du Centre-Oueste. $\mathrm{N}^{\circ}$ spécial 45.

Fagúndez Díaz, J. 2011. Catálogo de la flora vascular del concello de Ferrol (A Coruña). Jaca (Huesca), Spain: Jolube Consultor y Editor Botánico.

Foss, P. J. \& Doyle, G. J. 1988. Why has Erica erigena (the Irish Heather) a markedly disjunct distribution in Europe? Plants Today 1(5): 161-8.

Fossitt, J.A. 2000. A Guide to Habitats in Ireland. Kilkenny: The Heritage Council.

Gianguzzi, L., Cusimano, D., Bonventre, V., Romano, S. \& Ilardi, V. 2012. Bio-ecological, phytosociological and conservation aspects of relictual and disjointed populations of Simethis mattiazzi (Vandelli) Sacc. (Xanthorrhoeaceae) in the Channel of Sicily, Acta Botanica Gallica 159 (3): 303-318, DOI:10.1080/12538078.2012.737141. 
Godwin, H. 1975. A History of the British Flora. A Factual Basis for Phytogeography. Cambridge: Cambridge University Press.

Good, R. 1948. Geographical Handbook of the Dorset Flora. Dorset: Dorset Natural History and Archaeological Society.

Harvey, W. 1848. Account of a new British saxifrage. London Journal of Botany 7: 569-571.

Hennessy, H. 1867. On the Origin of the South European Plants found growing in the West and South of Ireland (Abstract) Proceedings of the Royal Irish Academy 10: 66-70.

Hickey, K. 2012. An Investigation into the Genetic Diversity of the Kerry Lily (Simethis planifolia), MSc thesis. Dublin: Trinity College Dublin.

Hodd, R. L. (2020). Simethis mattiazzii, Cahergarriff, Co. Cork. NPWS Rare Plant Survey 2019: Site Report No. 56. In: Perrin, P. M., Conaghan, J. P., Hodd, R. L. \& Martin, J. R. 2020. Rare Vascular Plant Survey 2019. Unpublished report. Dublin: National Parks and Wildlife Service, Department of Culture, Heritage and the Gaeltacht.

Hodgetts, N. G., Söderström, L., Blockeel, T. L., Caspari, S., Ignatov, M. S., Konstantinova, N.A., Lockhart, N., Papp, B., Schröck, C., Sim-Sim, M., Bell, D., Bell, N. E., Blom, H. H., Bruggeman-Nannenga, M. A., Brugués, M., Enroth, J., Flatberg, K. I., Garilleti, R., Hedenäs, L., Holyoak, D. T., Hugonnot, V., Kariyawasam, I., Köckinger, H., Kučera, J., Lara, F. \& Porley, R. D. 2020. An annotated checklist of bryophytes of Europe, Macaronesia and Cyprus, Journal of Bryology 42 (1): 1-116. DOI: 10.1080/03736687.2019.1694329

Kelleher, C., Brady, K. \& O'Neill, C. 2019. Forgotten ships and hidden scripts Archaeology Ireland 33 (4): 30-34.

Kent, M. 2012. Vegetation Description and Data Analysis: a Practical Approach. 2nd ed. Chichester, UK: Wiley-Blackwell.

Kress, W. J., Wurdack, K. J., Zimmer, E. A., Weigt, L. A., \& Janzen D. H. 2005. Use of DNA barcodes to identify flowering plants. Proceedings of the National Academy of Sciences of the United States of America (PNAS) 102 (23): 8369-8374; https://doi.org/10.1073/pnas.0503123102.

Kubitsky, K. 1998. The Families and Genera of Vascular Plants. Volume III Flowering Plants Monocotyledons Lilianae (except Orchidaceae). Berlin: Springer.

Lupton, D. 2009. Assessing the Conservation Status of the Kerry Lily (Simethis planifolia Gren. \& Godr.) Ireland. Kilkenny: The Heritage Council.

McBreen, K. \& Cruzan, M. B. 2004. A case of recent long-distance dispersal in the Piriqueta caroliniana complex. Journal of Heredity 95 (4): 356-361.

MacDonagh, M. 1903. The Life of Daniel O'Connell. London: Cassel \& Co., Ltd.

MacDonagh, O. 1988. The Hereditary Bondsman Daniel O'Connell 1775-1829. London: Weidenfeld \& Nicholson.

Maire, R. 1958. Flore de I'Afrique du Nord. Vol V Liliaceae. Encyclopédie Biologique LIV. Paris: Éditions Lechevalier.

Martin, J. R. 1998. A Species-Based Approach to the Conservation of Ireland's Threatened Vascular Plant Species, using Complementary in situ and ex situ Methodologies. PhD Thesis. Dublin: Trinity College, Dublin. 
Martínez Ortega, M. M. 2014. Simethis mattiazzii In: Talavera, S. Andrés, C., Arista, M., Fernández Piedra, M.P., Rico, E., Crespo, M.B., Quintanar, A., Herrero, A. \& Aedo, C., eds. Flora Iberica volume XX, Liliaceae-Agavaceae: 315-7.

Maxwell, W. H. 1832. Wild sports of the west, with legendary tales and local sketches. London: David Bryce.

Morales del Molino, C. \& Mateo, R. G. 2010. Simethis mattiazzi (Vandelli) Saccardo $[(=S$. planifolia (L.) Gren.], redescubierta para la flora de Castilla-La Mancha (España). Acta Botanica Malacitana 35: 148-150.

NPWS 2019. The Status of EU Protected Habitats and Species in Ireland. Volume 2: Habitat Assessments. Unpublished report. Dublin: National Parks and Wildlife Service, Department of Culture, Heritage and the Gaeltacht.

Parisod, C., Trippi, C. \& Galland, N. 2005. Genetic variability and founder effect in the Pitcher Plant Sarracenia purpurea (Sarraceniaceae) in populations introduced into Switzerland: from inbreeding to invasion. Annals of Botany 95 (2): 277-286.

Parnell, J. \& Curtis, T. 2012. Webb's An Irish Flora, $8^{\text {th }}$ ed. Cork: Cork University Press.

Pearman, D. \& Edgington, J. 2016. Simethis planifolia Kunth (Kerry Lily) in Britain and Ireland. BSBI News 132: 24-26.

Praeger, R LI. 1934. The Botanist in Ireland. Dublin: Hodges Figgis \& Co.

Preston, C.D., Pearman, D.A. \& Dines, T.D., eds. 2002. New Atlas of the British and Irish Flora. Oxford: Oxford University Press.

Scannell, M. J. P. \& O'Donnell, D. 1994. Report of Caha Mountains, West Cork (VC H3), 1st $2^{\text {nd }}$ August. Field Meeting reports for 1993. BSBI News 66: 54-55.

Scully, R. 1916. Flora of County Kerry, including the Flowering Plants, Ferns, Characeae, \&c. Dublin: Hodges Figgis.

Shaw, J., Lickey, E. B., Beck, J. T., Farmer, S. B., Liu, W., Miller, J., Siripun, K. C., Winder, C. T., Schilling, E. E. \& Small, R. L. 2005. The tortoise and the hare II: relative utility of 21 noncoding chloroplast DNA sequences for phylogenetic analysis. American Journal of Botany 92 (1): 142-166. https://doi.org/10.3732/ajb.92.1.142.

Shaw, J., Lickey, E. B., Schilling, E. E. \& Small, R. L. 2007. Comparison of whole chloroplast genome sequences to choose noncoding regions for phylogenetic studies in angiosperms: the tortoise and the hare III. American Journal of Botany 94 (3): 275-288. https://doi.org/10.3732/ajb.94.3.275.

Sheehy Skeffington, M. 2017. An alien immigrant? The story of Mackay's Heath, Erica mackayana, in Ireland. Moorea 17: 61-70.

Sheehy Skeffington, M. \& Van Doorslaer, L. 2015. Distribution and habitats of Erica mackayana and Erica $\times$ stuartir: new insights and ideas regarding their origins in Ireland. New Journal of Botany 6 (1): 164-177.

Stace, C. A. 2019. New Flora of Britain and Ireland. $4^{\text {th }}$ ed. Middlewood Green, Suffolk: C \& M Floristics.

Tison, J-M. \& de Foucault, B. (coords.) 2014. Flora Gallica. Flore de France. Mèze, France: Biotope.

Webb, D. A. 1980. Simethis. In: Tutin, T. G., Heywood, V. H., Burges, N. A., Moore, D. M., Valentine, D. H., Walters, S. M. \& Webb, D. A., eds Flora Europaea Volume 5 
Alismataceae To Orchidaceae (Monocotyledones). Cambridge: Cambridge University Press.

Webb, D. A. 1983. The flora of Ireland in its European context. Journal of Life Sciences, Royal Dublin Society 4 (2): 143-160.

Wyse Jackson, M., FitzPatrick, Ú., Cole, E., Jebb, M., McFerran, D., Sheehy Skeffington, M. \& Wright, M. 2016. Ireland Red List No. 10: Vascular Plants. Dublin, Ireland: National Parks and Wildlife Service, Department of Arts, Heritage, Regional, Rural and Gaeltacht Affairs.

Wyse Jackson, P. S. 1984. Comments on the status and ecology of Simethis mattiazzii (L.) Gren. in Co. Kerry. Bulletin of the Irish Biogeographical Society 8: 13-18.

Copyright retained by author(s). Published by BSBI under the terms of the Creative Commons Attribution 4.0 International Public License.

ISSN: $2632-4970$

https://doi.org/10.33928/bib.2020.02.309 